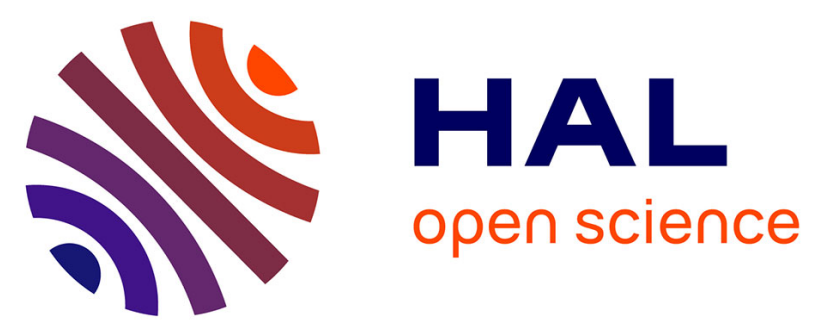

\title{
Catalysis by sulfides: Advanced IR/CO spectroscopy for the identification of the most active sites in HDS reactions
}

Laetitia Oliviero, Arnaud Travert, Elizabeth Dominguez Garcia, Jianjun Chen, Françoise Maugé

\section{To cite this version:}

Laetitia Oliviero, Arnaud Travert, Elizabeth Dominguez Garcia, Jianjun Chen, Françoise Maugé. Catalysis by sulfides: Advanced IR/CO spectroscopy for the identification of the most active sites in HDS reactions. Journal of Catalysis, 2021, 403, pp.87-97. 10.1016/j.jcat.2021.02.018 . hal-03424145

HAL Id: hal-03424145

https://hal-normandie-univ.archives-ouvertes.fr/hal-03424145

Submitted on 10 Nov 2021

HAL is a multi-disciplinary open access archive for the deposit and dissemination of scientific research documents, whether they are published or not. The documents may come from teaching and research institutions in France or abroad, or from public or private research centers.
L'archive ouverte pluridisciplinaire HAL, est destinée au dépôt et à la diffusion de documents scientifiques de niveau recherche, publiés ou non, émanant des établissements d'enseignement et de recherche français ou étrangers, des laboratoires publics ou privés.

$$
\text { Copyright }
$$




\title{
Catalysis by sulfides: Advanced IR/CO spectroscopy for the identification of the most active sites in HDS reactions
}

Laetitia Oliviero ${ }^{1}$, Arnaud Travert ${ }^{1}$, Elizabeth Dominguez Garcia ${ }^{1}$, Jianjun Chen ${ }^{1,2}$, Françoise Maugé ${ }^{1 *}$

\author{
${ }^{1}$ Normandie Univ, ENSICAEN, UNICAEN, CNRS, LCS, 14000 Caen, France \\ ${ }^{2}$ School of Environment, Tsinghua University, Beijing 100084, PR China' \\ *corresponding author - francoise.mauge@ensicaen.fr
}

\begin{abstract}
:
Sulfided CoMo supported on $\mathrm{TiO}_{2}, \mathrm{Al}_{2} \mathrm{O}_{3}$ or $\mathrm{SiO}_{2}$ were studied by $\mathrm{CO}$ adsorption followed by infrared spectroscopy (IR/CO). The inversion of adsorption isotherms obtained by IR spectroscopy (2D-IRIS method) was performed on promoted and non-promoted catalysts to verify that $v(\mathrm{CO})$ vibration contributions from $2090-2000 \mathrm{~cm}^{-1}$ can be attributed to CO/CoMoS interactions free of the contribution coming from CO/non-promoted S-edge of $\mathrm{MoS}_{2}$ nanoparticles. Second derivative function of the spectra evidences the presence of three different promoted sites. Promotion of $\mathrm{MoS}_{2}$ by in situ chemical vapor deposition allows to ascribe the different $v(\mathrm{CO} / \mathrm{CoMoS})$ contributions to partially or totally promoted M-edges $\left(2072-74 \mathrm{~cm}^{-1}, 2082-85 \mathrm{~cm}^{-1}\right)$ and partially-promoted S-edges (2054-57 $\mathrm{cm}^{-1}$ ). Then, IR/CO method highlights Co promotion on both edges (S-edge and M-edge) of $\mathrm{MoS}_{2}$ slabs. The hydrodesulfurization activity of these various catalysts shows that the total concentration of promoted sites is an important but not unique factor since the structures of the CoMoS sites modify their intrinsic activity. Parallel with the different CoMoS site amounts reveals that partially promoted M-edge sites of CoMo supported catalysts are the most active for hydrodesulfurization. This makes IR/CO a direct way to account for the most active types of promoted sites of CoMo supported catalysts.
\end{abstract}

Keywords: Hydrodesulfurization (HDS), Molybdenum disulfide $\left(\mathrm{MoS}_{2}\right)$, Support effect, Co carbonyl nitrosyl, Slab morphology, Active site structure, Infrared (IR) spectroscopy, CO adsorption 


\section{Introduction}

The production of clean fuels is more than ever a major industrial challenge to meet both the high demand for fuel and the urgency of environmental issues. Hydrotreatment is a key refinery process to remove impurities such as sulfur, nitrogen and metals even from highly contaminated feedstocks. The performance and stability of new generations of hydrotreating catalysts have been significantly improved. Even if the latest generations of hydrotreating catalysts are still essentially based on the classical composition i.e. sulfide $\mathrm{Mo}(\mathrm{W})$ promoted by $\mathrm{Co}(\mathrm{Ni})$ supported on alumina, a more thoughtful choice of support characteristics, the addition of dopants and, above all, a better control of the sulfidation stage allowed their performances to be greatly improved [1-3].

These optimizations were also obtained thanks to the development of well-adapted characterization methods. It should be mentioned that the characterization of these catalytic systems is challenging due to various specificities such as the sulfidation step (which leads to long-term contamination of the equipment), the high sensitivity of the sulfide catalysts to air-contact (which makes in situ characterizations much more relevant), the small size of the sulfide slabs $(\leq 2 \mathrm{~nm})$ and, most of all, the different forms of the elements present in the catalyst of which only a minority fraction is active for hydrotreatment. One can quote the alumina support, the Co spinel, the Co sulfide, the unpromoted $\mathrm{MoS}_{2}$ that are mostly inactive phases whereas, as early demonstrated by Topsøe's group [4-7], the so-called CoMoS phase actively participate to the reaction. This so-called CoMoS phase was related to the presence of Co atoms deposited on the edge of the $\mathrm{MoS}_{2}$ phase [4-7]. Among the various characterization techniques that account for atomic level structures of surface sites of in situ sulfided supported catalysts, infrared (IR) spectroscopy of probe molecule is one of the most relevant. In the early 80's, it was showed that the IR bands of adsorbed NO make possible to distinguish Mo sites from $\mathrm{Co}$ (or $\mathrm{Ni}$ ) sites and that nice relationships could be obtained between IR/NO and HDS activity [8-11]. In agreement with CoMoS model, IR/NO shows that optimizing the $\mathrm{MoS}_{2}$ slab dispersion and their edge coverage by promotors leads to improved HDS activity. NO adsorption has been extensively used for sulfided catalysts characterization by several groups [12-16]. However, NO has some drawbacks, the main one been its reactivity that may lead to corrosive adsorption on sulfide catalysts [17-19]. At the same period, IR spectroscopy of adsorbed $\mathrm{CO}$ was also developed and prove to be a powerful alternative for sulfide catalysts characterization. $\mathrm{CO}$ adsorption can be implemented at low temperature $(\sim 100 \mathrm{~K})$, which suppress the potential reactive interactions with some surface species, as well as of enhancing the interaction of CO with 
the weak adsorption sites of the sulfide phase and of the support. IR/CO gives rise to two main bands specific of unpromoted Mo sites (at $\sim 2110 \mathrm{~cm}^{-1}$ ) and CoMoS sites (at $\sim 2070 \mathrm{~cm}^{-1}$ ) (or NiMoS at $\sim 2122 \mathrm{~cm}^{-1}$ ) [20-26]. The determination of the molar extinction coefficients of these IR/CO band makes possible to account for the amount of sites and thus dispersion and degree of promotion of the sulfided slabs. Parallel between qualitative and quantitative IR/CO data and performances of the sulfided catalyst allows a strong insight into the active sites, as calculation of their TOF [27-29]

However, accurate spectral analysis points out that more than the two main bands initially quoted are presented in the IR/CO signal on sulfide phase. Indeed on unpromoted catalyst, according to the preparation methods (organic additives, temperature and pressure of sulfidation, nature of the support), IR spectra of Mo catalyst can show CO bands at $\sim 2110$ but also at $2070 \mathrm{~cm}^{-1}$ [30,31]. To go deeper insight into the structures of the edge sites of sulfide slabs parallels between IR/CO experiments and DFT calculations were done [30,32]. Theoretical calculations allowed to assign them to $\mathrm{CO}$ adsorbed on the two types of $\mathrm{MoS}_{2}$ edges. Further parallel between IR/CO experiments, and high resolution electron microscopy (HREM) and high angle annular dark field (HAADF) observations confirmed their assignments to $\mathrm{M}$ - and S-edge sites of $\mathrm{MoS}_{2}$ slabs. Determination of the molar extinction of these bands make IR/CO a way to account for the average shape of $\mathrm{MoS}_{2}$ slabs (S-/M- ratio).

In the present studies, we focus on the local structures of promoted edge sites of supported CoMo catalysts. Indeed, at least three components can be discriminated in the CoMoS signal. DFT calculations showed that many parameters can slightly modify the CO frequency such as the location of the CoMoS sites (S- or M-edges), the degree of promotion of the edges, the center for $\mathrm{CO}$ adsorption (Mo or $\mathrm{Co}$ ) [32]. Hence, to elucidate which site structure the experimentally observed CO bands correspond to, we studied sulfided catalysts with (i) different sulfided slabs morphologies by varying the nature of the support (silica, alumina, titania) or adding organic additive (citric acid (CA)), and thus varying the interaction sulfided phase-support, and (ii) step by step Co/Mo ratio changes by in situ introduction of controlled amounts of the Co promotor on $\mathrm{MoS}_{2}$ slabs presenting different morphologies. This was done using chemical vapor deposition (CVD) using $\left.\mathrm{Co}(\mathrm{CO})_{3} \mathrm{NO}\right)$, an in situ promotion method developed by our group [26]. In addition, in order to go deeper and discriminate between the different sites giving rise to bands with close wavenumbers, 2D Inversion of InfraRed Spectra (2D-IRIS) was used. This chemometric method allows recovering contributions of species differing by their affinity with the surface on overlapped spectra [33]. In the present work, 2D-IRIS was applied to the study of CO adsorption isotherms (at 
$100 \mathrm{~K}$ ) of Mo and CoMo sulfide catalysts. The insight provided by IR/CO characterization coupled with 2D-IRIS showed a step forward for characterization of Mo and CoMoS sites of supported sulfide catalysts. Hence, this makes IR/CO able to distinguish for the presence of non-promoted Mand S-edges sites, from partially promoted as well as totally promoted on M- and S-edges sites. Interestingly, this work allowed establishing relationships between atomic scale site structure and intrinsic HDS activity, and evidenced that the partially promoted M-edge sites present the highest TOF value.

\section{Materials and methods}

\subsection{Catalysts preparation}

\subsubsection{Oxide form preparation}

A series of promoted CoMo catalysts were prepared by wetness impregnation method on different supports: $\mathrm{Al}_{2} \mathrm{O}_{3}$ (gamma alumina, $248 \mathrm{~m}^{2} / \mathrm{g}$, Sasol), $\mathrm{SiO}_{2}$ (silica gel, $506 \mathrm{~m}^{2} / \mathrm{g}$, Merk) and $\mathrm{TiO}_{2}$ (mixture of anatase and rutile phases, $59 \mathrm{~m}^{2} / \mathrm{g}$, Degussa). Before impregnation, the supports were calcined and sieved between $0.2-0.5 \mathrm{~mm}$. The same molybdenum density ( 3 atoms Mo per $\left.\mathrm{nm}^{2}\right)$ and $\mathrm{Co} /(\mathrm{Co}+\mathrm{Mo})$ molar ratio equal to 0.3 were targeted. Heptamolybdate tetrahydrated salt (Alfa Aesar, 99\%) and cobalt nitrate (Alfa Aesar, 98\%) were used as molybdenum and cobalt precursors respectively. Both precursors were dissolved in an adjusted water volume and dispersed inside the pores of the support by a maturation step of 2 hours. After impregnation, the catalysts were dried at $383 \mathrm{~K}(3 \mathrm{~K} / \mathrm{min})$ during 16 hours and then calcined at $673 \mathrm{~K}(3 \mathrm{~K} / \mathrm{min})$ during 4 hours. So called oxide catalysts are then obtained.

\subsubsection{Sulfidation procedures}

Ex situ procedure: for ICP and TEM analysis, oxide catalysts were sulfided ex-situ in a glass reactor connected with $10 \% \mathrm{H}_{2} \mathrm{~S} / \mathrm{H}_{2}(30 \mathrm{ml} / \mathrm{min})$ flow at atmospheric pressure. Catalysts were heat from room temperature up to $623 \mathrm{~K}$ with a rate of $3 \mathrm{~K} / \mathrm{min}$ and then maintained at $623 \mathrm{~K}$ during $2 \mathrm{~h}$. After, the temperature was cooled down to $298 \mathrm{~K}$ under $\mathrm{N}_{2}$ flow $(30 \mathrm{ml} / \mathrm{min})$. Then the catalyst inside the reactor was introduced in a dry box under Ar flow, to avoid totally air contact.

For IR experiment and activity test, in situ sulfidation in the IR cell and reactor respectively was performed with the same parameters of gas flow, pressure and temperature. 


\subsubsection{CVD preparation in the IR cell}

Two types of $\mathrm{Mo} / \mathrm{Al}_{2} \mathrm{O}_{3}$ catalysts were prepared by an one-step pore volume impregnation method in the presence or absence of citric acid (CA). The impregnation solutions were firstly prepared with or without citric acid $\left(\mathrm{CA}, \mathrm{C}_{6} \mathrm{H}_{8} \mathrm{O}_{7} \cdot \mathrm{H}_{2} \mathrm{O}\right.$, PROLABO) and ammonium heptamolybdate tetrahydrate (AHT, $\left.\left(\mathrm{NH}_{4}\right)_{6} \mathrm{Mo}_{7} \mathrm{O}_{24} .4 \mathrm{H}_{2} \mathrm{O}, \mathrm{MERCK}\right)$. Sequentially, the pretreated $\gamma-\mathrm{Al}_{2} \mathrm{O}_{3}$ support

(Sasol, $252 \mathrm{~m}^{2} / \mathrm{g}$, pre-calcined in air at $723 \mathrm{~K}$ for 2 hours) was added into the solutions and strongly shaken for 2 hours. Finally, the catalysts were dried at $383 \mathrm{~K}$ for 3 hours. Note that these catalysts were not calcined in order to keep the citric acid in its initial form. Hereinafter, the $\mathrm{Mo} / \mathrm{Al}_{2} \mathrm{O}_{3}$ catalysts prepared with and without $\mathrm{CA}$ are denoted as $\mathrm{Mo}(\mathrm{CA}) / \mathrm{Al}_{2} \mathrm{O}_{3}$ and $\mathrm{Mo} / \mathrm{Al}_{2} \mathrm{O}_{3}$, respectively. The Mo content corresponds to 3 atoms Mo per $\mathrm{nm}^{2}$, and the molar ratio of CA/Mo is 1 for $\mathrm{Mo}(\mathrm{CA}) / \mathrm{Al}_{2} \mathrm{O}_{3}$ catalyst.

Cobalt was introduced onto in-situ sulfided $\mathrm{Mo} / \mathrm{Al}_{2} \mathrm{O}_{3}$ and $\mathrm{Mo}(\mathrm{CA}) / \mathrm{Al}_{2} \mathrm{O}_{3}$ catalysts by a chemical vapor deposition (CVD) technique. After the sulfidation stage, $\mathrm{Mo} / \mathrm{Al}_{2} \mathrm{O}_{3}$ or $\mathrm{Mo}(\mathrm{CA}) / \mathrm{Al}_{2} \mathrm{O}_{3}$ catalyst was firstly evacuated at $623 \mathrm{~K}$ for $1 \mathrm{~h}$ in the IR cell with the final pressure reaches $10^{-3} \mathrm{~Pa}$. Subsequently, small calibrated doses of $\mathrm{Co}(\mathrm{CO})_{3} \mathrm{NO}$ vapor $\left(0.8852 \mathrm{~cm}^{3}\right)$ at different pressures (precisely measured) was introduced onto the catalyst surface at room temperature. These doses correspond to $12,21,32,50,85,115,185,290,394 \mathrm{umol} / \mathrm{g}_{\text {catalyst }}$ (from 0.07 to $2.32 \% \mathrm{Co}$ ). After that, the sample was re-sulfided at $623 \mathrm{~K}$ for 2 hours in $10 \% \mathrm{H}_{2} \mathrm{~S} / \mathrm{H}_{2}$ gas flow.

\subsection{Catalyst characterization}

\subsubsection{Textural properties}

Nitrogen adsorption/desorption isotherms were measured on calcined supports and oxide catalysts at $77 \mathrm{~K}$ using Micrometrics Model ASAP 2020 volumetric adsorption analyzer. Samples were degassed at $523 \mathrm{~K}$ under vacuum for $12 \mathrm{~h}$ prior to analysis. Specific surface areas were determined from the BET equation.

\subsubsection{Elemental analysis by Inductively Coupled Plasma (ICP)}

Inside the dry box, $50 \mathrm{mg}$ of sample was dissolved in $100 \mathrm{~mL}$ of a mixture of hydrofluoric acid, aqua regia, boric acid and water. Quantification of molybdenum, cobalt and sulfur amount present in the catalysts was then determined by Inductively Coupled Plasma Atomic Emission Spectrometry (ICP-AES) using a PerkinElmer Optima 330DV ICP instrument. 


\subsubsection{Transmission Electron Microscopy (TEM)}

Transmission electron microscopy (TEM) was performed on a JEOL 2200 FS FEG operated at $200 \mathrm{kV}$. After ex-situ sulfidation and transfer into the glove box, suspensions in ethanol absolute were prepared. TEM analyses were carried out using a few drops of the suspension on a copper grid. All TEM images were recorded at the same magnification and digitized using a 4092x4092 $\mathrm{px}^{2}$ GATAN Ultrascan camera. Slab length and stacking degree distributions of sulfide slabs were determined manually from at least 300 slabs. The measure was performed using Mesurim program. The TEM pictures and image results of analysis are presented in SI.

\subsubsection{Infrared spectroscopy}

Infrared characterizations were performed in a low temperature cell adapted to adsorb carbon monoxide at very low temperature $(100 \mathrm{~K})$. Firstly, oxide catalyst in wafer form was activated in situ at $623 \mathrm{~K}$ under $10 \% \mathrm{H}_{2} \mathrm{~S} / \mathrm{H}_{2}$ flow during 2 hours. Then, the catalyst was flushed with Ar during 10 minutes and left $1 \mathrm{~h}$ under vacuum at $623 \mathrm{~K}$. Finally, it was cooled down to $100 \mathrm{~K}$ under high vacuum $\left(1.10^{-4} \mathrm{~Pa}\right)$.

$\mathrm{CO}$ adsorption was performed in two different ways. The conventional experiments were performed introducing small CO doses by a calibrated volume and then a equilibrium pressure of $133 \mathrm{~Pa}$ to obtain sites saturation. Isotherm experiments were also carried out increasing equilibrium CO pressure up to sites saturation. All IR spectra were recorded with a Nicolet Magna 550 FT-IR spectrometer equipped with a MCT detector. Every spectrum was normalized to a disc of $5 \mathrm{mg} / \mathrm{cm}^{2}$ and all experiments were duplicated (maximum area variation of 5\%). Equilibrium/saturated spectra were decomposed using OMNIC program and Voigt function. The wavenumbers of band maxima were determined by polynomial interpolation of the negative peaks of the second derivative of the spectra. The precision on these frequencies was in the order of $+/-0.6 \mathrm{~cm}-1$ in the worst case (i.e. for spectra with S/N ratio of 20) and much higher in all other cases [34].

\subsubsection{Inversion of infrared spectra (2D-IRIS, [33])}

2D-IRIS applied to spectra of adsorbed species recorded at equilibrium pressures is a data processing methodology consisting in assessing the energy distribution of the adsorption sites. Such a distribution $\varphi(\gamma)$ can be defined as:

$$
\varphi(\gamma) d \gamma=n(\gamma)
$$

where $\gamma$ is the reduced Gibbs free energy of adsorption, $\gamma=\Delta_{a d s} G / R T=-\ln K_{a d s}^{\circ}(T)$ and $n(\gamma)$ is the number of sites characterized by a reduced adsorption Gibbs free energy $\gamma$. Assuming 
that the local adsorption isotherm $\theta(\gamma, p)$ has the same functional form for all sites the adsorption isotherm is given by:

$$
q(p)=\int_{-\infty}^{\infty} \varphi(\gamma) \theta(\gamma, p) d \gamma
$$

where $q(p)$ is the total uptake at pressure $p$. Inversion of this integral equation allows recovering the distribution function $\varphi(\gamma)$ from the experimental isotherm $q(p)$ [35-37]

The above expression can be extended to the evolution of the absorbance of the IR spectra of the adsorbate recorded at equilibrium pressure:

$$
a(v, p)=\int_{-\infty}^{\infty} f(v, \gamma) \theta(\gamma, p) d \gamma
$$

Where $a(v, p)$ is the absorbance measured at wavenumber $v$ and pressre $p$ and the 2D distribution function $f(v, \gamma)$ is related to the distribution function of adsorption sites by:

$$
f(\nu, \gamma)=\frac{\epsilon(\gamma, v)}{S} \varphi(\gamma)
$$

Where $\epsilon(\gamma, v)$ is the absorption coefficient at wavenumber $v$ of the species of reduced Gibbs free adsorption energy $\gamma$, and $S$ is the surface area of the self-supported disc of catalyst. Inversion of the above integral equation allows recovering the distribution function $f(v, \gamma)$ from the set of experimental spectra $a(v, p)$ recorded at equilibrium pressures of the probe molecule or optical isotherms. The numerical procedure to recover the distributions functions has been detailed elsewhere [33]. The analysis of the spectra with 2D-IRIS was carried out with SpectroChemPy [38] using Langmuir local isotherms and a reference pressure $\mathrm{p}^{\circ}=133 \mathrm{~Pa}$ (1 Torr).

\subsection{Catalytic activity: Thiophene test}

Thiophene reaction was carried out in a differential reactor at $623 \mathrm{~K}$ and atmospheric pressure with a thiophene partial pressure of $8 \mathrm{kPa}$ in a mixture of hydrogen $(91.2 \mathrm{kPa})$ and $\mathrm{H}_{2} \mathrm{~S}(2.1 \mathrm{kPa})$. The outlet gas was analyzed by Varian 3900 gas chromatograph equipped with flame ionization (FID) detector. Thiophene reaction was running during $18 \mathrm{~h}$ to obtain a stable reaction rate. The reaction rate was calculated as $\mathrm{r}_{\mathrm{HDS}}=(\mathrm{F} / \mathrm{m}) \cdot \mathrm{X}$, where $\mathrm{F} / \mathrm{m}$ is the molar flow rate of thiophene per gram of sulfided catalyst and $\mathrm{X}$ is thiophene conversion which is below 5\%. The initial mass of oxide catalyst (around $25 \mathrm{mg}$ precisely weighted) was corrected to take into account the sulfidation step using a correction factor calculated from the infrared experiments. 


\section{Results}

\subsection{General characterizations of (Co)Mo catalysts}

Table 1 summarizes the physicochemical properties of the sulfide catalysts on different supports. It can be noted that $\mathrm{CoMo} / \mathrm{SiO}_{2}$ catalyst loss $2 / 5$ of the surface area presented by the support after the impregnation. This was previously observed on non-promoted catalysts prepared in similar way and ascribed to the small pore size of the support $(6 \mathrm{~nm})$ [29].

ICP analysis of the sulfided samples confirm the target loading in Co and Mo. The sulfur content is high enough for $\mathrm{CoMo} / \mathrm{Al}_{2} \mathrm{O}_{3}$ and $\mathrm{CoMo} / \mathrm{TiO}_{2}$ to have complete Mo sulfidation. For $\mathrm{CoMo} / \mathrm{TiO}_{2}$, the $\mathrm{S} /(\mathrm{Mo}+\mathrm{Co})$ ratio is greater than 2, which accounts for a partial sulfidation of the support itself. Conversely, the lower $\mathrm{S} /(\mathrm{Co}+\mathrm{Mo})$ value for $\mathrm{CoMo} / \mathrm{SiO}_{2}$ catalyst suggest uncomplete Mo sulfidation.

Table 1. Textural properties and elemental analysis of catalysts

\begin{tabular}{|c|c|c|c|c|c|}
\hline \multirow{2}{*}{ Catalysts } & \multicolumn{2}{|c|}{ Surface area $\left(\mathrm{m}^{2} / \mathrm{g}\right)$} & \multirow{2}{*}{$\%$ wt Mo } & \multirow{2}{*}{$\begin{array}{c}\% \mathrm{wt} \\
\mathrm{Co}\end{array}$} & \multirow{2}{*}{$\begin{array}{c}\text { at. ratio } \\
\mathrm{S} /(\mathrm{Mo}+\mathrm{Co})\end{array}$} \\
\hline & Support & Oxide catalyst & & & \\
\hline $\mathrm{CoMo} / \mathrm{SiO}_{2}$ & 506 & 307 & 16 & 3 & 1.7 \\
\hline $\mathrm{CoMo} / \mathrm{Al}_{2} \mathrm{O}_{3}$ & 248 & 235 & 8 & 2 & 2.1 \\
\hline $\mathrm{CoMo} / \mathrm{TiO}_{2}$ & 59 & 58 & 2 & 0.4 & $2.8^{*}$ \\
\hline
\end{tabular}

* $\mathrm{TiO}_{2}$ support is partially sulfided

Transmission electron microscopy was performed to determine the slab length and stacking number for promoted catalysts. A minimum of 60 images (Figure SI1) were taken for each sample to be sure about the validity of the measure. Distribution of slabs length and stacking are shown in Figure SI2 for promoted catalysts supported on $\mathrm{Al}_{2} \mathrm{O}_{3}, \mathrm{SiO}_{2}$ and $\mathrm{TiO}_{2}$. The average of slab length and stacking number are summarized in Table 2. $\mathrm{CoMo} / \mathrm{Al}_{2} \mathrm{O}_{3}$ catalyst shows the smallest slab length and stacking number. $\mathrm{CoMo} / \mathrm{TiO}_{2}$ and $\mathrm{CoMo} / \mathrm{SiO}_{2}$ catalysts have close slab length and $\mathrm{CoMo} / \mathrm{SiO}_{2}$ catalyst have around double stacking number.

Table 2. Average slabs length and stacking number for CoMo catalysts supported on $\mathrm{Al}_{2} \mathrm{O}_{3}, \mathrm{SiO}_{2}$ and $\mathrm{TiO}_{2}$.

\begin{tabular}{|c|c|c|}
\hline Catalyst & Average length (nm) & Average stacking number \\
\hline $\mathrm{CoMo} / \mathrm{SiO}_{2}$ & 4.5 & 3.3 \\
\hline $\mathrm{CoMo} / \mathrm{Al}_{2} \mathrm{O}_{3}$ & 2.9 & 1.4 \\
\hline $\mathrm{CoMo} / \mathrm{TiO}_{2}$ & 4.7 & 1.7 \\
\hline
\end{tabular}




\subsection{IR/CO characterization}

\subsubsection{Effect of support nature of (Co)Mo catalysts}

$\mathrm{CO}$ adsorption at low temperature followed by FTIR spectroscopy (IR/CO) was performed on sulfide (Co)Mo catalysts supported on $\mathrm{Al}_{2} \mathrm{O}_{3}, \mathrm{SiO}_{2}$ and $\mathrm{TiO}_{2}$. The spectra obtained at $133 \mathrm{~Pa}$ equilibrium pressure of $\mathrm{CO}$ are compared with those obtained on Mo catalysts in Figure 1. The spectra of the three Mo catalysts presents bands at about 2114 and $2070 \mathrm{~cm}^{-1}$ that account for CO adsorption on M- and S-edges Mo sites, respectively. As already shown, the marked changes in band ratios point out that different $\mathrm{MoS}_{2}$ morphologies were obtained for Mo catalysts supported on $\mathrm{Al}_{2} \mathrm{O}_{3}, \mathrm{SiO}_{2}$ and $\mathrm{TiO}_{2}$ [29]. Figure 1A shows the comparison of IR spectra of $\mathrm{CO}$ adsorption at equilibrium pressure for $\mathrm{Mo} / \mathrm{Al}_{2} \mathrm{O}_{3}$ and $\mathrm{CoMo} / \mathrm{Al}_{2} \mathrm{O}_{3}$ catalysts. $v(\mathrm{CO} / \mathrm{S}$-edge $)$ band shows a maximum at $2070 \mathrm{~cm}^{-1}$, while the overlapping stretching bands of $v(\mathrm{CO} / \mathrm{CoMoS})$ show a maximum at $2074 \mathrm{~cm}^{-1}$. Similar case is presented for $(\mathrm{Co}) \mathrm{Mo} / \mathrm{SiO}_{2}$ catalyst as shows Figure 1B. Close wavenumber is recorded for $v(\mathrm{CO} / \mathrm{S}$-edge $)$ band detected at $2065 \mathrm{~cm}^{-1}$ and $v(\mathrm{CO} / \mathrm{CoMoS})$ band with a maximum at $2075 \mathrm{~cm}^{-1}$. For $\mathrm{Mo} / \mathrm{TiO}_{2}$ showing mostly (97\%) M-edge sites, the eventual contribution of $v(\mathrm{CO} / \mathrm{S}$-edge $)$ in the $v(\mathrm{CO} / \mathrm{CoMoS})$ massif can be neglected (Figure $1 \mathrm{C})$. Thus, one question arises for catalysts that present $\mathrm{MoS}_{2}$ nanoparticles with S-edge sites: does the massif ascribed to $v(\mathrm{CO} / \mathrm{CoMoS})$ contain also contribution of the $v(\mathrm{CO} / \mathrm{S}$-edge $)$ band? To answer this question, the 2D-IRIS method will be applied to $(\mathrm{Co}) \mathrm{Mo} / \mathrm{Al}_{2} \mathrm{O}_{3}$ and $(\mathrm{Co}) \mathrm{Mo} / \mathrm{SiO}_{2}$ catalysts.

A

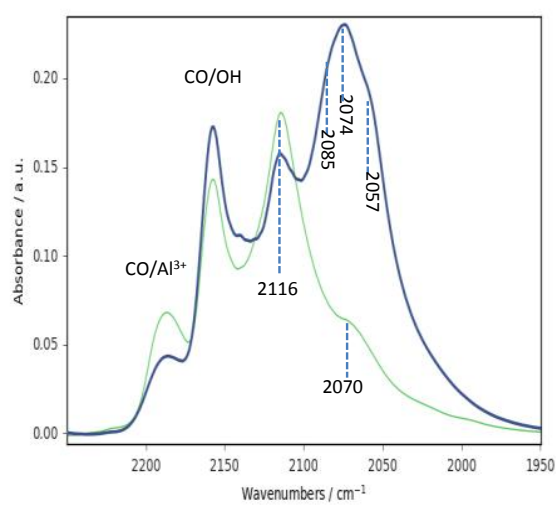

B

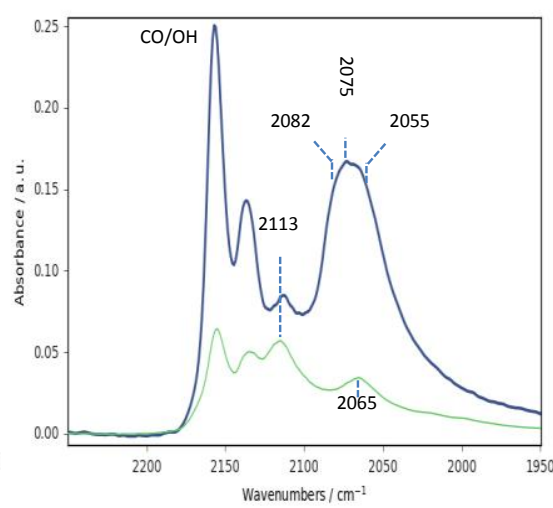

C

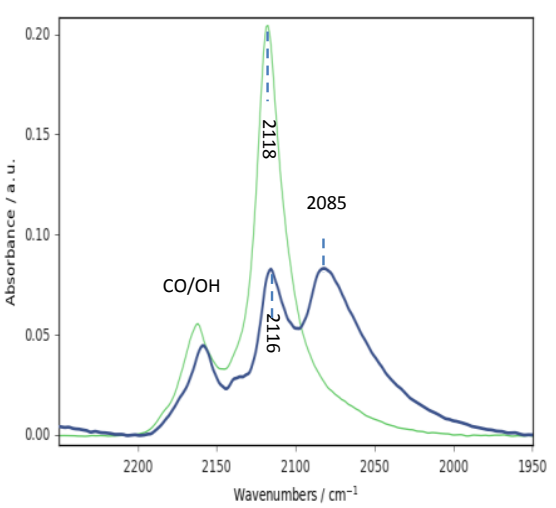

Figure 1. IR spectra of CO at $133 \mathrm{~Pa}$ equilibrium pressure for Mo (green line) and CoMo (thick blue line) sulfide catalysts supported on $\mathrm{Al}_{2} \mathrm{O}_{3}(\mathrm{~A}), \mathrm{SiO}_{2}(\mathrm{~B})$ and $\mathrm{TiO}_{2}(\mathrm{C})$. 


\subsubsection{D Inversion of IR Spectra (2D-IRIS) of CO adsorbed on (Co)Mo catalysts}

2D IRIS allows recovering contributions of distinct species differing by their affinity with the surface to overlapped spectra. To this aim, CO adsorption was carried at low temperature (100 $\mathrm{K}$ ) and various $\mathrm{CO}$ equilibrium pressures (from $\sim 0$ to $133 \mathrm{~Pa}$ ) on non-promoted and promoted catalysts. Figure SI3 shows the total area of CO bands versus the equilibrium CO pressures on the $\mathrm{CoMo} / \mathrm{Al}_{2} \mathrm{O}_{3}$ catalyst. A plateau is recorded at $133 \mathrm{~Pa}$, and this pressure can be taken as the pressure at which nearly all sites are saturated by $\mathrm{CO}$. This procedure was used for all the catalysts, and for all of them at $133 \mathrm{~Pa}$ of equilibrium pressure the plateau was reached. The set of IR spectra recorded at equilibrium pressures will be referred to as "spectroscopic isotherms". Figure 2 shows the spectroscopic isotherms obtained for $\mathrm{Mo} / \mathrm{Al}_{2} \mathrm{O}_{3}$ and $\mathrm{CoMo} / \mathrm{Al}_{2} \mathrm{O}_{3}$ catalysts (top) and the 2Ddistribution functions of absorbance $f(v, \gamma)$ (bottom). The 2D-maps of these functions display spots which locations on the wavenumber axis $v$ match the wavenumbers of the main bands of the IR spectra. The position of these spots on the affinity scale axis $(\gamma)$ corresponds to the reduced Gibbs free energy of $\mathrm{CO}$ adsorption on the corresponding sites. The 2D distribution function obtained on $\mathrm{Mo} / \mathrm{Al}_{2} \mathrm{O}_{3}$ shows a well-defined spot at $v=2155 \mathrm{~cm}^{-1} / \gamma=-3.0\left(\mathrm{Al}_{2} \mathrm{O}_{3} \mathrm{OH}\right.$ groups $), v=2110 \mathrm{~cm}^{-1} /$ $\gamma=-5.5$ (M-edges) and $\gamma=v=2070 \mathrm{~cm}^{-1} / \gamma=-4.8$ (S-edge). The relative positions of the latter spots indicated that $\mathrm{CO}$ is significantly stronger on M-edges that on S-edges, while adsorption on $\mathrm{Al}_{2} \mathrm{O}_{3}$ hydroxy groups by $\mathrm{H}$-bonding corresponds to significantly weaker interactions. The evolution of the band characteristic of $\mathrm{CO}$ adsorption on $\mathrm{Al}_{2} \mathrm{O}_{3}$ Lewis acid sites $\left(\sim 2220-2180 \mathrm{~cm}^{-}\right.$ ${ }^{1}$ ) leads to a well-defined spot at $\sim 2220 \mathrm{~cm}^{-1}$ corresponding to $\mathrm{CO}$ adsorption on the strongest $\mathrm{Al}^{3+}$ centers of low coordination $\left(\mathrm{Al}^{\mathrm{IV}}\right.$ ), and to an arch extending from $v=2190 \mathrm{~cm}^{-1} / \gamma=-5$ to $v=2175$ $\mathrm{cm}^{-1} / \gamma=-3.5$. It corresponds to $\mathrm{CO}$ adsorption of weaker Lewis acid sites $\left(\mathrm{Al}^{\mathrm{VI}}\right)$ of the alumina surface. This arc-shaped distribution function of absorbance results from the continuous shift of the band with $\mathrm{CO}$ pressure, due to both the heterogeneity of the corresponding sites and the lateral interactions between neighboring $\mathrm{CO}$ molecules which increases with $\mathrm{CO}$ coverage. It is worth noticing that similar, but much less pronounced distortion is also observed for $\mathrm{CO}$ adsorption on the M-edge. Finally spots of weak intensity also appear at the highest values of the $\gamma$ scale (i.e. lowest affinity of the surface) at 2155 and $2145 \mathrm{~cm}^{-1}$. They correspond to small contributions of bands characteristic to adsorption on the $\mathrm{OH}$ groups and physisorbed $\mathrm{CO}$, respectively.

The distribution function obtained on $\mathrm{CoMo} / \mathrm{Al}_{2} \mathrm{O}_{3}$ catalyst differs from that obtained on the non-promoted catalyst by a shift of the signal related to adsorption on weak Lewis acid sites and $\mathrm{OH}$ groups toward higher values of $\gamma$. This reflects a weakening of the acidity of these sites which could originate from the insertion of Co ions in the alumina lattice and/or long-range interaction 
with the sulfide phase. Regarding the distribution function related to $\mathrm{CO}$ adsorption on the sulfide phase, it is striking that while the position of the spot corresponding to the non-promoted sites does not change much $\left(v=2110 \mathrm{~cm}^{-1}, \gamma=-5\right)$, the contributions associated to the broad and intense bands characteristic of the promoted phase appear at significantly more negative $\gamma$ values $(\sim-5.5--6.5)$. This indicates that such bands correspond to $\mathrm{CO}$ species more strongly bound to the sulfide phase. Moreover, the position of the maxima becomes also more negative as the wavenumber decreases, which is consistent with a strengthening of the adsorption with back-donation from the sulfide phase $\mathrm{d}$ electrons to the $\pi * \mathrm{CO}$ orbitals. This is very different from the case of the non-promoted catalyst for which the distribution function associated to the band characteristic of $\mathrm{CO}$ adsorbed on the S-edge is located at significantly higher $\gamma$ values that the one associated to the non-promoted Medge. Moreover, the distribution function obtained for the promoted catalyst does not show any contribution at the position observed for CO adsorbed on the S-edge of the non-promoted catalyst . This is a strong indication that the correspond sites (Mo centers on non-promoted S-edge) are absent on $\mathrm{CoMo} / \mathrm{Al}_{2} \mathrm{O}_{3}$.
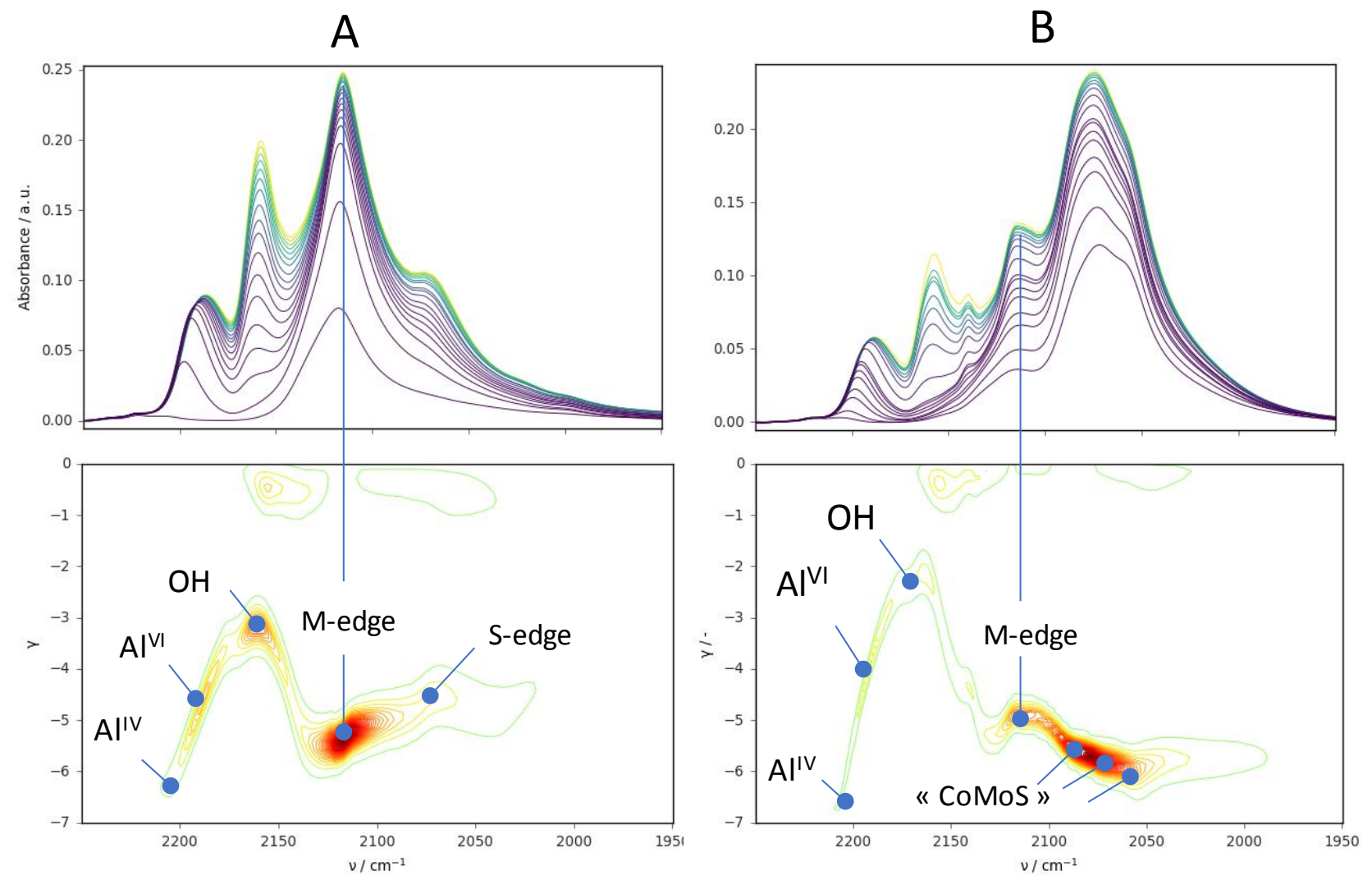

Figure 2. Spectroscopic isotherms (top) and 2D-distribution functions of the absorbances (bottom) of CO adsorbed on (A) $\mathrm{Mo} / \mathrm{Al}_{2} \mathrm{O}_{3}$ and (B) $\mathrm{CoMo} / \mathrm{Al}_{2} \mathrm{O}_{3}$ catalysts. 
The same procedure was applied to silica supported catalysts. Figure 3 shows the spectroscopic isotherms and the distribution functions of the absorbances obtained for nonpromoted and promoted catalysts supported on $\mathrm{SiO}_{2}$. The bands corresponding to $\mathrm{CO}$ adsorption on silanol groups $\left(2155 \mathrm{~cm}^{-1}\right)$, physisorbed and oxysulfide [39] species (2135 $\left.\mathrm{cm}^{-1}\right)$ led for both catalysts to distribution of absorbances located at high $\gamma$ values, indicating a weak adsorption. Adsorption on the sulfide phase of the non-promoted $\mathrm{Mo} / \mathrm{SiO}_{2}$ led to two resolved bands at 2110 and $2070 \mathrm{~cm}^{-1}$ assigned to CO adsorption on non-promoted M-edge and S-edges, respectively. The corresponding distribution functions are close from those obtained for the $\mathrm{CO}$ bands assigned to the sulfide phase of $\mathrm{Mo} / \mathrm{Al}_{2} \mathrm{O}_{3}$ (Figure 2A) with maxima located at close positions. Again, the $\gamma$ value obtained for $\mathrm{CO}$ adsorption on the $\mathrm{S}$ edge $(\gamma=-4,8)$ was larger than that corresponding to $\mathrm{CO}$ adsorption on the M-edge $(\gamma=-5,5)$. By contrast, on $\mathrm{CoMo} / \mathrm{SiO}_{2}$ catalyst, $\gamma$ value obtained for $\mathrm{CO}$ adsorption on the M-edge increases $(\gamma=-4,8)$ and the distribution functions associated to the CO bands located at $\sim 2080-2060 \mathrm{~cm}^{-1}$ has maxima located at slightly lower $\gamma$ values. This indicates that these latter sites lead to stronger $\mathrm{CO}$ adsorption, in line with the results obtained on $\mathrm{Al}_{2} \mathrm{O}_{3}$.
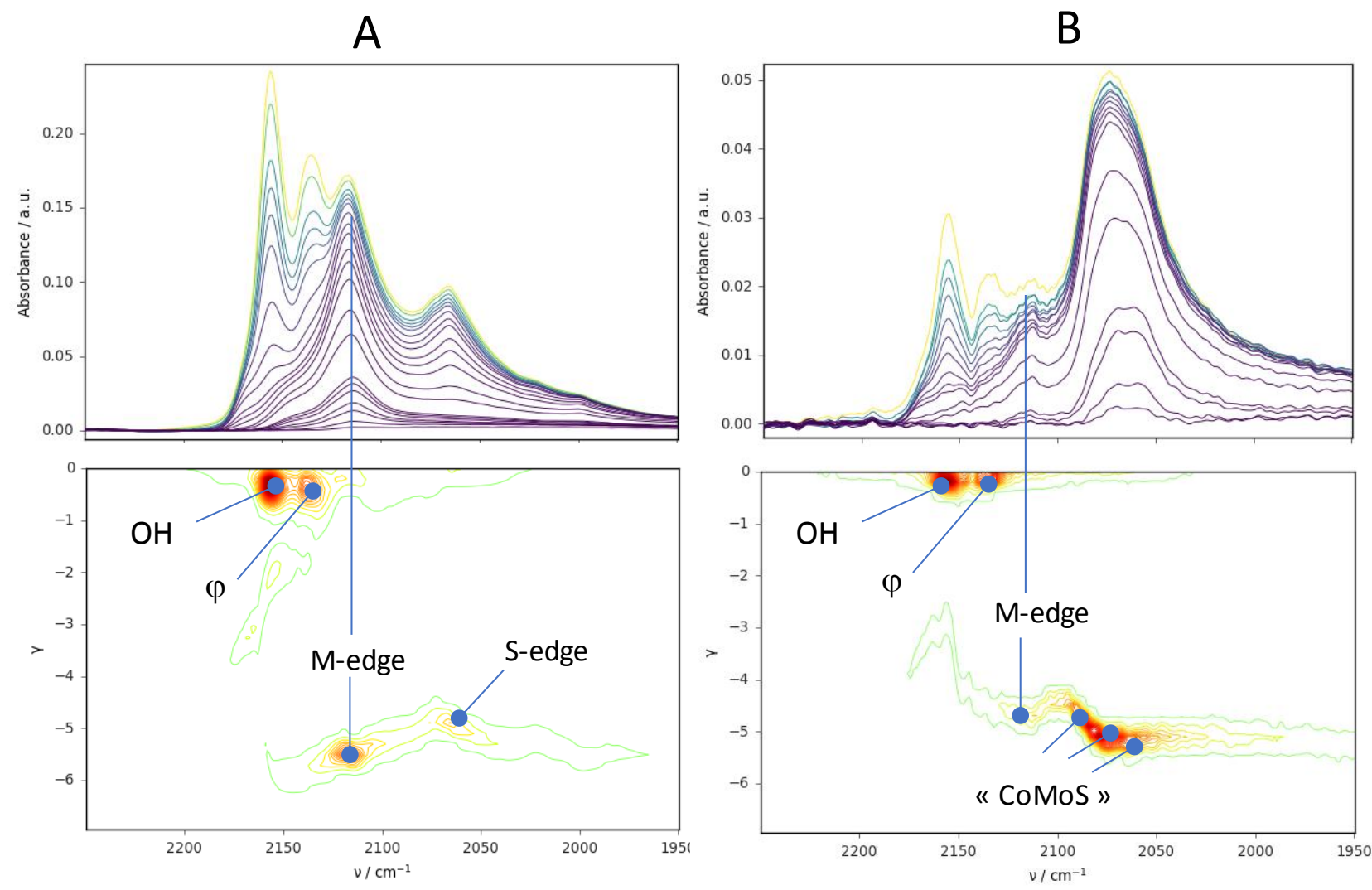

Figure 3. Spectroscopic isotherms (top) and 2D-distribution functions of the absorbances (bottom) of CO adsorbed on (A) $\mathrm{Mo} / \mathrm{SiO}_{2}$ and (B) and $\mathrm{CoMo} / \mathrm{SiO}_{2}$ catalysts. 


\subsubsection{Evidence of different promoted sites by IR/CO•}

IR/CO spectra from small $\mathrm{CO}$ doses up to saturation at equilibrium pressure $(133 \mathrm{~Pa})$ for sulfide $\mathrm{CoMo} / \mathrm{Al}_{2} \mathrm{O}_{3}$ catalyst are shown in Figure 4A. Considering the second derivatives of the spectra obtained for low doses, three principal components can be defined in the $v(\mathrm{CO} / \mathrm{CoMoS})$ range at 2057, 2074 and $2085 \mathrm{~cm}^{-1}$. Since no contribution at $2065 \mathrm{~cm}^{-1}$ is revealed [40]; it can be concluded that $\mathrm{Co}_{9} \mathrm{~S}_{8}$ is not formed on $\mathrm{CoMo} / \mathrm{Al}_{2} \mathrm{O}_{3}$.

A

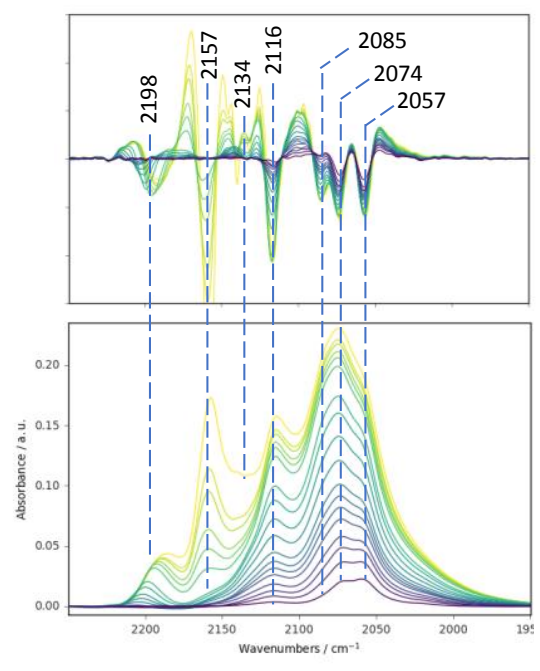

B

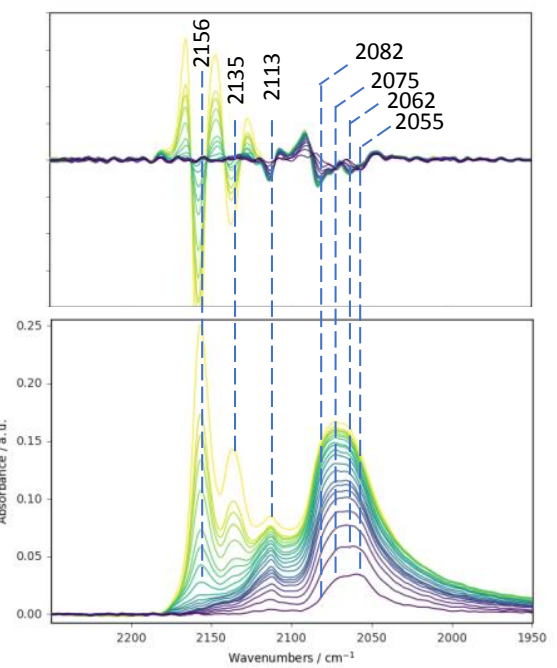

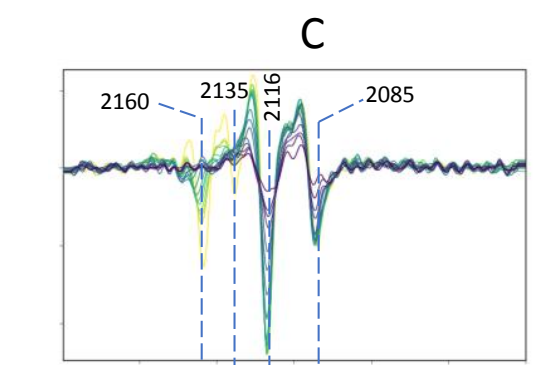

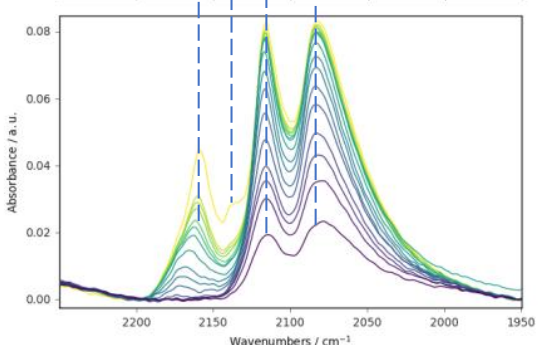

Figure 4. Bottom: IR spectra of $\mathrm{CO}$ adsorption from small $\mathrm{CO}$ doses up to saturation at equilibrium pressure (133Pa).

Top: second derivative of IR spectra. A: $\mathrm{CoMo} / \mathrm{Al}_{2} \mathrm{O}_{3}, \mathrm{~B}: \mathrm{CoMo} / \mathrm{SiO}_{2} ; \mathrm{C}: \mathrm{CoMo} / \mathrm{TiO}_{2}$

Similar results were obtained on $\mathrm{CoMo} / \mathrm{SiO}_{2}$ i.e. three main components located at $\sim 2055$, $\sim 2075$, and $2082 \mathrm{~cm}^{-1}$ can be assigned to $\mathrm{CO}$ adsorption on promoted sites with different environments (Figures 4B). A fourth component at $\sim 2062 \mathrm{~cm}^{-1}$ was detected on $\mathrm{CoMo} / \mathrm{SiO}_{2}$ which is ascribed to $\mathrm{Co}_{9} \mathrm{~S}_{8}$ formation. On $\mathrm{CoMo} / \mathrm{TiO}_{2}, \mathrm{CO}$ adsorption on the sulfide phase lead to less intense bands because of the lower amount of sulfide phase (Figures 4C). Consequently, the second derivative had a smaller signal to noise ratio and did not allow distinguishing several components.

For consistency, the components determined from the second derivatives on $\mathrm{CoMo} / \mathrm{Al}_{2} \mathrm{O}_{3}$ and $\mathrm{CoMo} / \mathrm{SiO}_{2}$ were considered as a basis for partitioning the area of the bands assigned to $\mathrm{CO}$ adsorption on non-promoted and promoted sites on the spectra obtained at CO saturation. Two peaks at about 2098 and $2110 \mathrm{~cm}^{-1}$ were used for non-promoted sites [27,41]; three peaks at about 
$2083 \mathrm{~cm}^{-1}, 2073 \mathrm{~cm}^{-1}$ and $2057 \mathrm{~cm}^{-1}$ were used to account for the three components characteristic of promoted sites. Low frequency peaks (at 2038, 2020 and $2000 \mathrm{~cm}^{-1}$ ) have also been used to account for the broadening of the CoMoS band in the low wavenumber range. The decompositions were performed using OMNIC program and using Voight functions and are presented in SI. Quantification of sites was performed distinguishing non- and promoted sites and using extinction coefficients of 15 and $43 \mathrm{~cm} \cdot \mu \mathrm{mol}^{-1}$ respectively [28,40]. The quantification of the Mo sites and main components of CoMoS sites is summarized in Table 3.

Table 3: Sites quantification for CoMo catalysts supported on $\mathrm{Al}_{2} \mathrm{O}_{3}, \mathrm{SiO}_{2}$ and $\mathrm{TiO}_{2}$

\begin{tabular}{|c|c|c|c|c|c|}
\hline & Non promoted sites & \multicolumn{4}{|c|}{ Promoted sites } \\
\hline \multirow{2}{*}{$\begin{array}{l}\text { Wavenumber }\left(\mathrm{cm}^{-}\right. \\
\left.{ }^{1}\right)\end{array}$} & \multirow[t]{2}{*}{ 2116-2099 } & \multirow{2}{*}{$\begin{array}{l}\text { Total } \\
2090-2000\end{array}$} & \multicolumn{3}{|c|}{ Main components } \\
\hline & & & $2082-2085$ & $2070-2074$ & $2054-2057$ \\
\hline Catalyst & \multicolumn{5}{|c|}{$\mu \mathrm{mol}$ edge sites $/ \mathrm{g}_{\text {catalyst }}$} \\
\hline $\mathrm{CoMo} / \mathrm{SiO}_{2}$ & 25 & 29 & 6 & 9 & 10 \\
\hline $\mathrm{CoMo} / \mathrm{Al}_{2} \mathrm{O}_{3}$ & 61 & 72 & 19 & 26 & 17 \\
\hline $\mathrm{CoMo} / \mathrm{TiO}_{2}$ & 28 & 21 & 9 & 5 & 4 \\
\hline
\end{tabular}

\subsubsection{Effect of Co deposition amount on the promoted site bands}

The overlapping $v(\mathrm{CO} / \mathrm{CoMoS})$ bands detected between 2090 and $2000 \mathrm{~cm}^{-1}$, has to be attributed to specific Co environment as totally or partially promoted edges. For this purpose, CoMoS site formation upon cobalt addition using CVD method was performed in-situ in the IR cell. Increasing amounts of $\mathrm{Co}(\mathrm{CO})_{3} \mathrm{NO}$ were contacted with sulfided $\mathrm{Mo} / \mathrm{Al}_{2} \mathrm{O}_{3}$ and $\mathrm{Mo}(\mathrm{CA} / \mathrm{Mo}=1) / \mathrm{Al}_{2} \mathrm{O}_{3}$ catalysts and the resulting edge sites were probed by $\mathrm{CO}$ adsorption (Figures SI7 and SI8). These two catalysts were chosen since the addition of citric acid leads to a change in the slab morphology of $\mathrm{Mo} / \mathrm{Al}_{2} \mathrm{O}_{3}$ catalyst, i.e. the catalyst prepared with citric acid has higher S/M-edge ratio than the one prepared without citric acid [28]. In order to highlight the position of the different band components, Figure 5 shows the second derivative of the $\mathrm{CO}$ adsorption spectra obtained after increasing CVD doses. In both experiments, two CO stretching bands appear at 2055 and $2072 \mathrm{~cm}^{-1}$ from the first CVD dose up to the last one. Both bands increase with Co addition at the same time than the band ascribed to $\mathrm{CO}$ in interaction with non-promoted M-edge sites decreases. The only difference between the two samples is the disappearance of the band around $2070 \mathrm{~cm}^{-1}$ ascribed to $v(\mathrm{CO} / \mathrm{S}$-edge $)$ of unpromoted catalyst, from the first CVD dose indicating the promotion of this edge as well. Thus, these two bands at 2055 and $2072 \mathrm{~cm}^{-1}$ can be ascribed to 
partially promoted sites, but without any evidence of edge site location. Moreover, a third band appears at $2082 \mathrm{~cm}^{-1}$ with the last $\mathrm{Co}(\mathrm{CO})_{3} \mathrm{NO}$ doses. Accordingly, this $2082 \mathrm{~cm}^{-1}$ band can be attributed to fully promoted edge. This attribution is further confirmed by the fact that the $2082 \mathrm{~cm}^{-1}$ band starts to be visible earlier for $\mathrm{Mo} / \mathrm{Al}_{2} \mathrm{O}_{3}$ catalyst than for $\mathrm{Mo}(\mathrm{CA}) / \mathrm{Al}_{2} \mathrm{O}_{3}$ catalyst. Indeed, $\mathrm{MoS}_{2}$ slabs are smaller on $\mathrm{Mo}(\mathrm{CA} / \mathrm{Mo}=1) / \mathrm{Al}_{2} \mathrm{O}_{3}$ and thus present higher amount of total edge sites than $\mathrm{Mo} / \mathrm{Al}_{2} \mathrm{O}_{3}$ catalyst does [42].

A

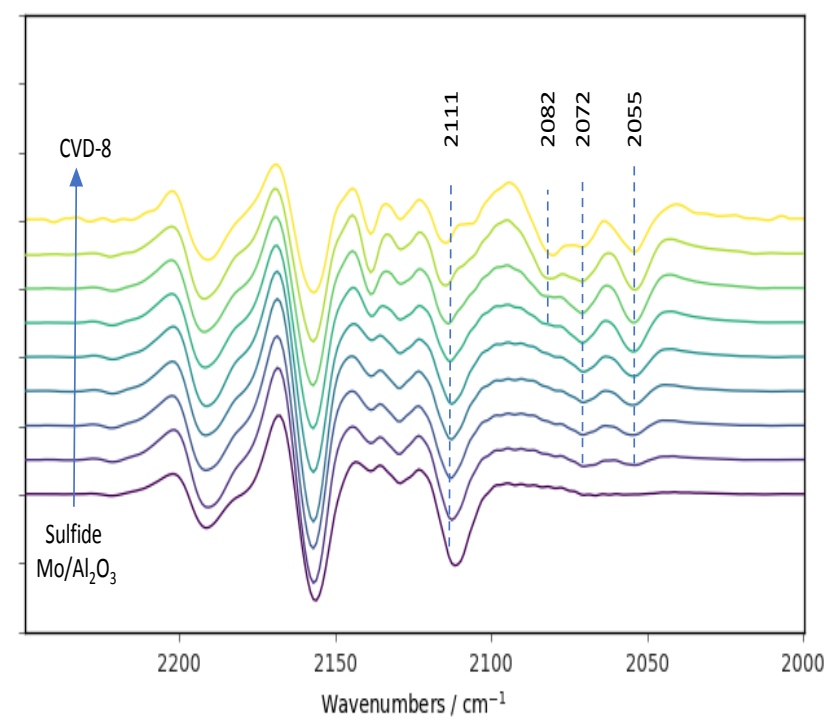

B

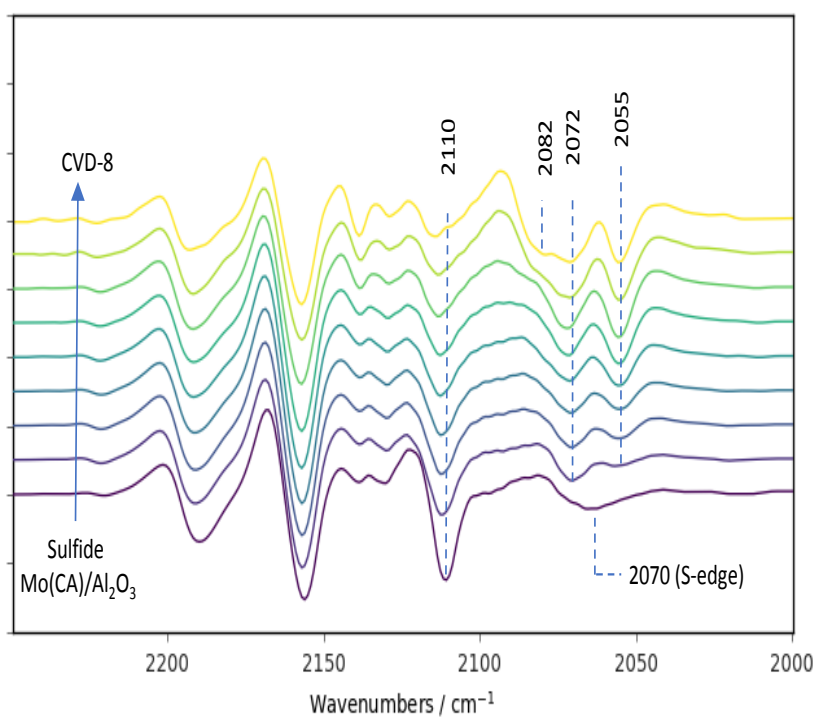

Figure 5. Second derivatives of IR spectra of $\mathrm{CO}$ on $(\mathrm{Co}) \mathrm{Mo} / \mathrm{Al}_{2} \mathrm{O}_{3}$ catalysts prepared by CVD. (A) Co deposition on $\mathrm{Mo} / \mathrm{Al}_{2} \mathrm{O}_{3}$, (B) Co deposition on $\mathrm{Mo}(\mathrm{CA}) / \mathrm{Al}_{2} \mathrm{O}_{3}$. From violet to yellow: nonpromoted to Co-promoted catalysts at increasing Co content (from 0.07 to $2.32 \%$ wt Co deposited).

\subsection{Catalytic activity}

Thiophene HDS activity rate of CoMo catalysts are presented in Figure $6 \mathrm{a}$ and Figure $6 \mathrm{~b}$ on a mass and surface area basis respectively, knowing that the surface area of the support varies but the loading was kept constant at $3 \mathrm{Mo}$ at. $\mathrm{nm}_{\text {support }}{ }^{-2}$. In both cases, $\mathrm{CoMo} / \mathrm{Al}_{2} \mathrm{O}_{3}$ catalyst presents the highest catalytic activity. However, $\mathrm{CoMo} / \mathrm{SiO}_{2}$ catalyst presents higher $\mathrm{HDS}$ rate than $\mathrm{CoMo} / \mathrm{TiO}_{2}$ if the HDS rate is represented per gram of catalyst, while $\mathrm{CoMo} / \mathrm{TiO}_{2}$ catalyst presents higher HDS rate than $\mathrm{CoMo} / \mathrm{SiO}_{2}$ catalyst when HDS rate is expressed per surface area. 

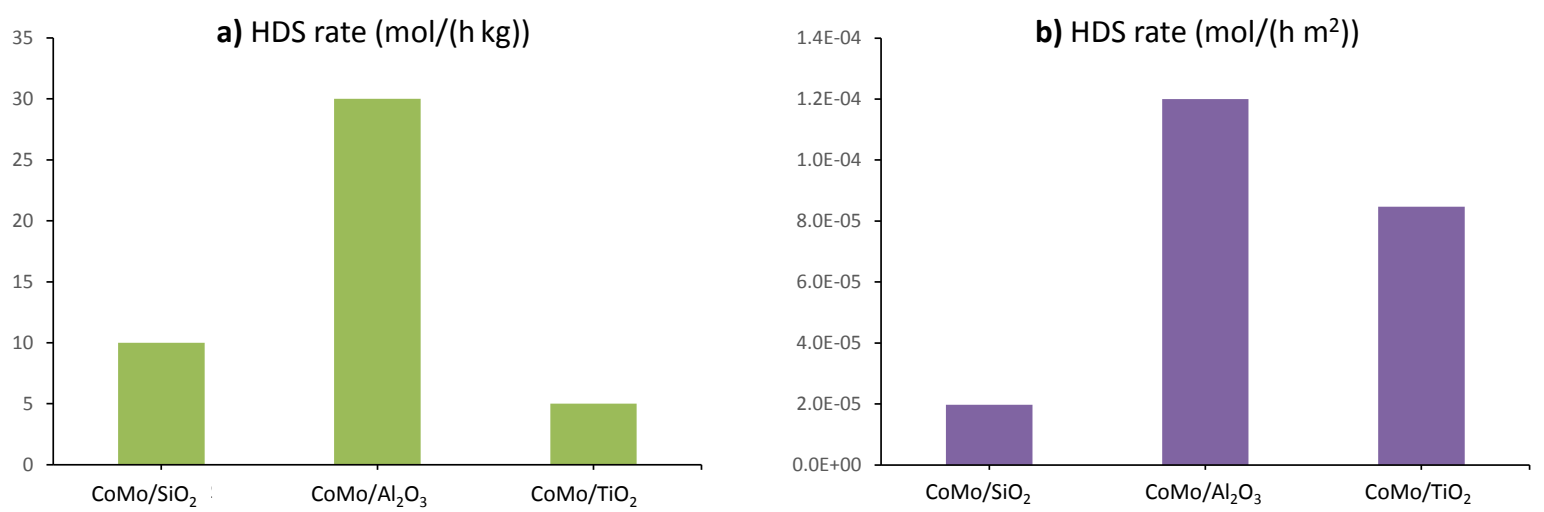

Figure 6. Thiophene reaction rates per gram (a) and per surface area (b) on promoted catalysts

It is well known that thiophene is not an optimal molecule to study the selectivity of HDS catalysts. However, some differences between the product distributions were found as shows Figure 7. In particular, it appears that $\mathrm{CoMo} / \mathrm{TiO}_{2}$ favors the $\mathrm{HYD}$ pathway as was shown for $\mathrm{Mo} / \mathrm{TiO}_{2}$ catalyst since the percentage of THT formed is significantly higher for this catalyst as compared to $\mathrm{CoMo} / \mathrm{Al}_{2} \mathrm{O}_{3}$.

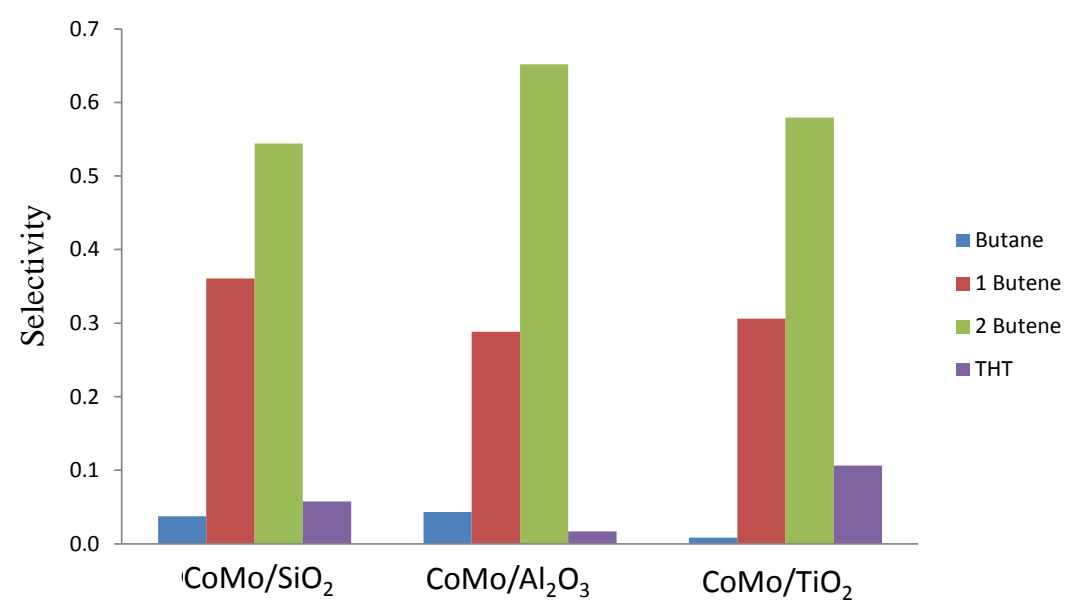

Figure 7. Percentage of different products converted in thiophene HDS reaction for CoMo catalysts supported on $\mathrm{Al}_{2} \mathrm{O}_{3}$, $\mathrm{SiO}_{2}$ and $\mathrm{TiO}_{2}$

\section{Discussion}

Understanding CoMoS site formation is a requirement for the catalyst improvement. For that, series of catalysts using different supports have been studied. The goal of using different supports was to obtain $\mathrm{MoS}_{2}$ slabs with different morphologies, varying the metal-support interaction, and then to determine the Co affinity for M- and/or S-edge sites. For similar purpose, CVD Co 
deposition were also performed on alumina-supported $\mathrm{MoS}_{2}$ slabs with different morphologies. Thus, the edge decoration by Co has been studied by the IR/CO coupled with 2D-IRIS method. From the stretching frequencies and the Gibbs free energies of $\mathrm{CO}$ on the corresponding adsorption site $(\gamma)$, it is possible distinguishing $\mathrm{M}$ - from S-edge sites for non-promoted catalysts as well as three different promoted sites. The challenge now is to specify the structure of these different CoMoS sites and to determine if they present different intrinsic activities.

\subsubsection{Location of the CoMoS site}

In previous studies, metal-support interaction was reported as the main factor that influences $\mathrm{MoS}_{2}$ slab characteristics $[29,43,44]$. Indeed, IR/CO spectra clearly shows that S-/M-edge ratio of Mo catalysts change with the support nature. Thus, the strongest metal-support interaction reported for $\mathrm{Mo} / \mathrm{TiO}_{2}$ catalyst leads to a really low $\mathrm{S}$-/M-edge ratio that corresponds to a triangle-like slab shape. Besides, the weakest metal-support interaction of $\mathrm{Mo} / \mathrm{SiO}_{2}$ catalyst leads to a high $\mathrm{S}-/ \mathrm{M}$ edge ratio corresponding to a truncated triangular shape near to a perfect hexagon. And, catalyst with medium metal-support interaction as $\mathrm{Mo} / \mathrm{Al}_{2} \mathrm{O}_{3}$ catalyst presents slabs of truncated triangular shape in between the two previous catalysts.

In order to gain information on the edge location of the promotor and knowing that the nature of the support drastically changes the S-/M- edge ratio of the supported $\mathrm{MoS}_{2}$ slabs, the promoted sites/non-promoted sites ratio (promotion degree for CoMo catalysts, calculated from Table 3) was plotted with the S-/M-edge ratio (morphology for the Mo catalysts) for the three supports as shows Figure 8a. For higher S-/M-edge ratio, higher promotion degree is obtained but without a clear relationship. It can also be noticed that the promotion degree is higher than the S/M- edge ratio. This result can be interpreted as Co decoration occurs on both S- and M-edge sites of $\mathrm{MoS}_{2}$ nanoparticles. Additionally, as shows Figure 2, the decrease of non-promoted M-edge sites pointed out on IR spectra of CoMo catalysts and the absence of non-promoted S-edge site evidenced by 2D-IRIS on $\mathrm{CoMo} / \mathrm{Al}_{2} \mathrm{O}_{3}$ catalysts are also in favored of promoted sites formed on both sulfide slab edges. Nevertheless, one has to recall that changes in morphology between unpromoted and promoted catalysts can occur. STM images had showed on Au support [45] the variation of triangular shaped slabs toward more truncated ones by promotion. However, in case where changes of sulfided morphology are unlikely, as for in situ Co deposition on $\mathrm{MoS}_{2} / \mathrm{Al}_{2} \mathrm{O}_{3}$, the S-edge band is not more detected from the first CVD Co doses on Mo(CA) catalyst. This result is also in favor of promoted sites formed on S-edges. Hence, there are strong indications that Co decoration occurs on both S- and M-edge sites of supported $\mathrm{MoS}_{2}$ nanoparticles. 
a)

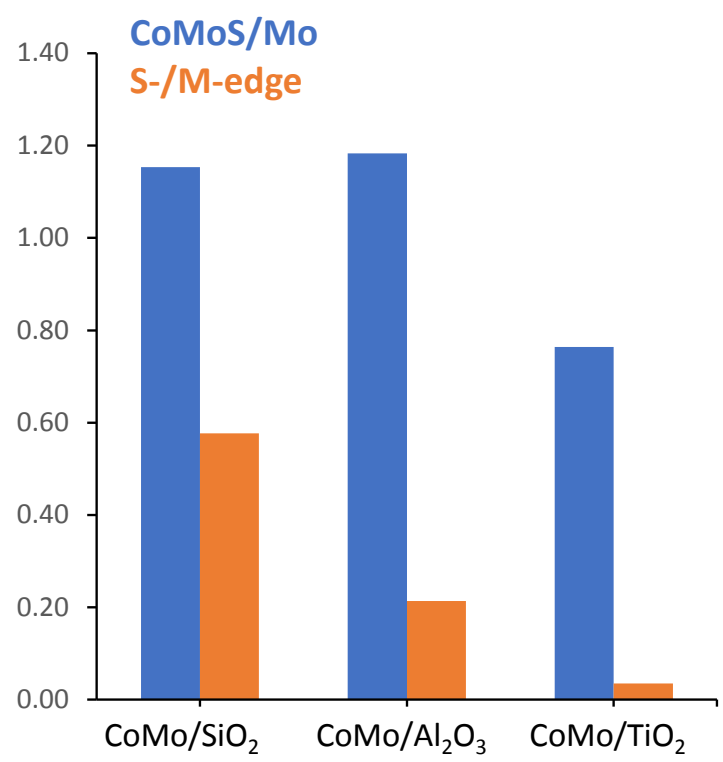

b)

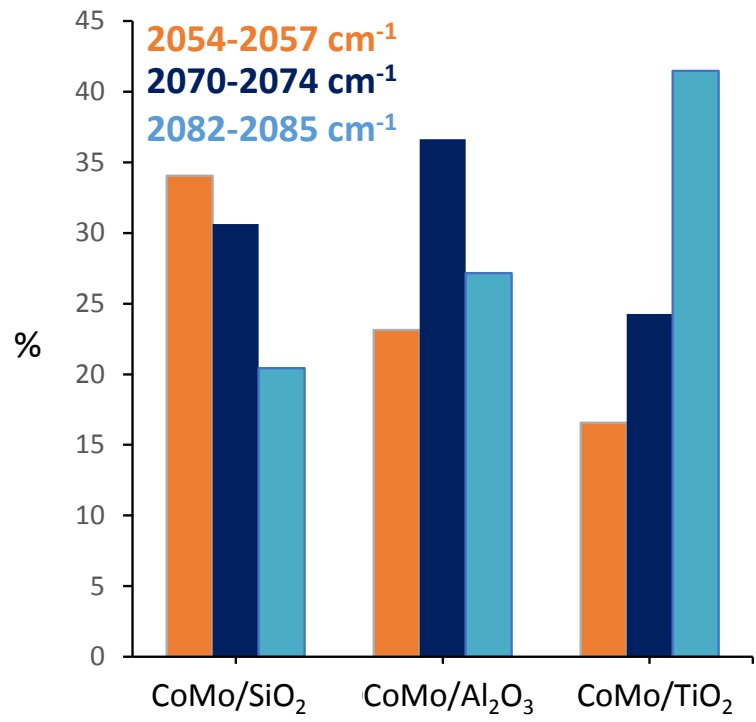

Figure 8. a) Comparison between $\mathrm{MoS}_{2}$ morphology detected for non-promoted catalysts and promotion degree obtained for promoted catalysts. b) Contribution of the three main $v(\mathrm{CO} / \mathrm{CoMoS})$ components for CoMo catalysts supported on $\mathrm{Al}_{2} \mathrm{O}_{3}, \mathrm{SiO}_{2}$ and $\mathrm{TiO}_{2}$.

\subsubsection{Structure of the CoMoS sites}

On the spectra of CVD experiments of the two Mo catalysts, the second derivative method points out the presence of three components whose detection depends on the amount of Co deposited (Figure 5). From these intensity changes with $\mathrm{Co} / \mathrm{Mo}$ ratio, one can ascribe the bands at 2055 and $2072 \mathrm{~cm}^{-1}$ to partially promoted sites, while that at $2082 \mathrm{~cm}^{-1}$ can be attributed to fully promoted edge. But without any specification about their edge location.

On the spectra of classically prepared catalysts supported on the different oxides, three CoMoS band are also detected at very close wavenumbers. Parallel between the morphology of $\mathrm{MoS}_{2}$ phase on the different supports (Figure 8a) and the proportion of the three different promoted sites (Figure 8b) was performed to get information about the edge location. Figure 8b points out that their proportions strongly depend on the support nature. It appears that the component at 2054-57 $\mathrm{cm}^{-1}$ follows the same trend than the S-/M-edge ratio detected for non-promoted catalyst. It could be then proposed that this component corresponds to partially promoted S-edge sites. On the other hand, the component detected at 2082-85 $\mathrm{cm}^{-1}$ follows the reverse trend. It could be ascribed to totally promoted M-edge sites. As for the band at $2072-74 \mathrm{~cm}^{-1}$ that corresponds to partially 
promoted sites, the determination of the location is less direct. One can note the decrease of this component when the component specific to fully-promoted M-edge sites (2082-85 $\left.\mathrm{cm}^{-1}\right)$ increases suggesting the assignment of the band at $2072-74 \mathrm{~cm}^{-1}$ to partially promoted M-edge sites.

Previous paper by Travert et al reported the changes of CO stretching vibrations calculated by DFT versus the different promotion degree $(0,25 \%, 100 \%)$ of $\mathrm{M}$ - and S- edges of Co-promoted $\mathrm{MoS}_{2}$ slabs [32]. The DFT calculations show that promoted sites can present many different structures giving rise to different $v(\mathrm{CO})$ frequencies some being separated by only few $\mathrm{cm}^{-1}$ (Table SI4). This points out that the calculated wavenumbers cannot be directly used to assign the bands experimentally observed. However, analysis of the calculated values on $\mathrm{CO}$ frequencies of the different sulfide sites, shows interesting trends: $i$ ) the $v(\mathrm{CO})$ frequency of the fully-promoted sulfide sites is greater than that of partially promoted sulfide sites, which well agrees with the attribution we previously drawn from CVD experiments, $i i)$ for similar site structure, the $v(C O)$ wavenumber of $\mathrm{CO}$ on M-edge sites is higher than the wavenumber of $v(\mathrm{CO})$ on $\mathrm{S}$-edge sites. This last point is an additional support to propose that band at $2072-74 \mathrm{~cm}^{-1}$, that is located at greater wavenumber than $2054-57 \mathrm{~cm}^{-1}$ band, correspond to partially promoted sites on M-edge.

Finally, from the advanced IR/CO results obtained by 2D-IRIS, Co CVD and comparison between (Co)Mo supported on the three different supports and from comparison with the trends resulting from the DFT calculation, the structure of the sites corresponding to the three $\mathrm{CO} / \mathrm{CoMoS}$ bands could be determined.

\subsubsection{Influence of the CoMoS site structure on the HDS activity}

The metal-support interaction has been revealed as a factor that influences the CoMoS site formation and affects the promotor localization and promotion degree of the edge. Thus, the impact of the CoMoS site structures on the HDS activity has been studied on the CoMo catalysts supported on the different supports. Firstly, Figure 9a that compares the concentration of non-promoted and promoted sites with thiophene HDS rate, does not show any clear relationship. In particular, $\mathrm{CoMo} / \mathrm{TiO}_{2}$ that presents amount of promoted sites higher to that of $\mathrm{CoMo} / \mathrm{Al}_{2} \mathrm{O}_{3}$, clearly exhibits a lower activity. This highlights that the concentration of CoMoS sites is an important factor but not the only factor that determines HDS activity. Indeed, Figure $8 \mathrm{~b}$ points out a nice parallel between the HDS activity and the amount of partially promoted sites (bands at 2072-74 and 2054-57 cm ${ }^{-1}$ ). $\mathrm{CoMo} / \mathrm{Al}_{2} \mathrm{O}_{3}$ that presents the highest concentration of partially promoted sites, has the highest activity. Compared to $\mathrm{CoMo} / \mathrm{Al}_{2} \mathrm{O}_{3}, \mathrm{CoMo} / \mathrm{TiO}_{2}$ catalyst presents a lower amount of partially promoted sites but a higher amount of totally promoted sites, and a lower activity. 
a) Site concentration

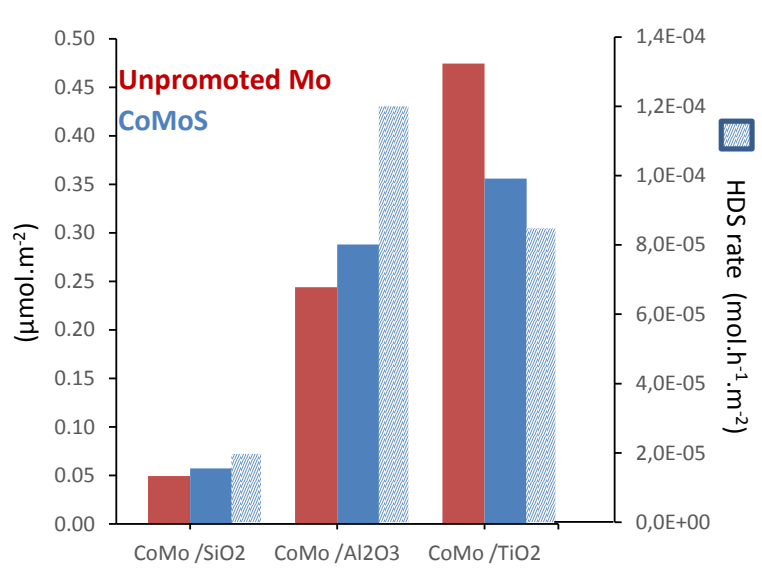

b) CoMoS site concentration

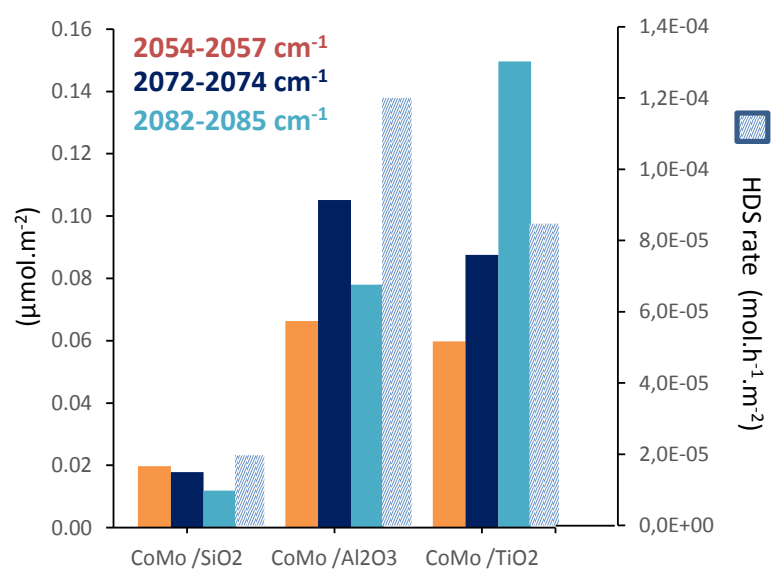

Figure 9. Comparison of a) unpromoted and promoted sites concentration, b) concentration of the 3 types of CoMoS sites with thiophene $\mathrm{HDS}$ rate for CoMo catalysts supported on $\mathrm{Al}_{2} \mathrm{O}_{3}, \mathrm{SiO}_{2}$ and $\mathrm{TiO}_{2}$

Table 4. TOF values (in $\mathrm{h}^{-1}$ ) of non- and promoted sites for CoMo catalysts supported on $\mathrm{Al}_{2} \mathrm{O}_{3}, \mathrm{SiO}_{2}$ and $\mathrm{TiO}_{2}$.

\begin{tabular}{|l|l|l|l|}
\hline Catalyst & TOF (unpromoted Mo)* & TOF $(\mathrm{CoMoS})$ & TOF $(\mathrm{CoMoS}) / \mathrm{TOF}$ (unpromoted Mo) \\
\hline $\mathrm{CoMo} / \mathrm{SiO}_{2}$ & 44 & 307 & 7 \\
\hline $\mathrm{CoMo} / \mathrm{Al}_{2} \mathrm{O}_{3}$ & 18 & 401 & 22 \\
\hline $\mathrm{CoMo} / \mathrm{TiO}_{2}$ & 35 & 191 & 5 \\
\hline
\end{tabular}

*data from [29]

To go further, the turn over frequency (TOF) of promoted sites on the different supports was calculated. It was calculated taking into account the TOF values obtained previously for nonpromoted sites on Mo catalysts on the three supports [29] and the concentration of non- and promoted sites such as :

$$
\mathrm{r}_{\mathrm{HDS}}=\mathrm{n}_{\mathrm{M} \text {-edge }} \cdot \mathrm{TOF}_{\mathrm{M} \text {-edge }}+\mathrm{n}_{\mathrm{CoMoS}} \cdot \mathrm{TOF}_{\mathrm{CoMoS}}
$$

where $\mathrm{n}$ is site concentration, $\mathrm{r}_{\mathrm{HDS}}$ is thiophene HDS rate and TOF (turnover frequency).

Table 4 shows that the $\mathrm{TOF}(\mathrm{CoMoS})$ values are different for the three catalysts. $\mathrm{CoMo} / \mathrm{Al}_{2} \mathrm{O}_{3}$ presents the highest $\mathrm{TOF}(\mathrm{CoMoS})$ value and the highest promotion factor (TOF (CoMoS)/TOF (unpromoted Mo)), whereas $\mathrm{CoMo} / \mathrm{TiO}_{2}$ has the lowest $\mathrm{TOF}(\mathrm{CoMoS})$ value as well as the lowest promotion factor, and $\mathrm{CoMo} / \mathrm{SiO}_{2}$ presents in-between values. These differences are related to different proportions of the various types of CoMoS site structures that constitute the promoted sites of these catalysts. Parallel between $\mathrm{TOF}_{\mathrm{CoMoS}}$ values and proportion of S- and M-edge partially 
promoted sites allowed to go further in the identification of the most active partially promoted sites. $\mathrm{CoMo} / \mathrm{Al}_{2} \mathrm{O}_{3}$ that presents the highest proportion of partially promoted M-edge sites $\left(2072-74 \mathrm{~cm}^{-1}\right)$ compared to partially promoted S-edge sites $\left(2054-56 \mathrm{~cm}^{-1}\right)$ has the highest $\mathrm{TOF}_{\mathrm{CoMoS}}$ whereas $\mathrm{CoMo} / \mathrm{SiO}_{2}$ that has a lower proportion of partially promoted M-edge sites compared to partially promoted S-edge sites presents a lower $\mathrm{TOF}_{\mathrm{CoMoS}}$.

This highlights that partially promoted M-edge sites present greater intrinsic activity than partially promoted S-edge sites and that totally promoted M-edge sites. Previous works already reported changes in the promoted site properties according to the degree of promotion $[44,45]$. DFT calculations shows that the sulfur-metal bond energy at the M-edge decreases with the increase of the Co content on this edge. From XPS quantification, DFT models and toluene-hydrogenation measurements, Gandubert et al showed that the mixed Co-Mo sites at the M-edge of CoMoS particles present greater intrinsic catalytic activity than sites with higher Co amount that is in nice agreement with our results. In conclusion, the structure of the promoted sites strongly impacts their intrinsic activities. This study highlights that IR/CO is able to report for the environment of the different promoted sites formed on supported CoMo catalysts and in particular to account for the most active promoted sites i.e. the partially promoted M-edge sites through specific IR/CO band (at $\left.2073 \mathrm{~cm}^{-1}\right)$.

\section{Conclusions}

The IR spectroscopy of CO adsorbed on supported sulfide CoMo catalysts that present different sulfide slab morphologies (S-/M- edge ratios), allowed to provide evidence for the presence of promoted sites with different structures. The 2D-IRIS method that is based on the inversion of $\mathrm{CO}$ adsorption isotherms obtained by IR spectroscopy was applied for the first time to sulfide catalysts to account for the Gibbs free adsorption energies for each adsorption sites of the support and the sulfide phase. 2D-IRIS method allowed to discard the presence of non-promoted Sedge sites in the contribution characterizing promoted sites $\left(2090-2000 \mathrm{~cm}^{-1}\right)$. By applying second derivative functions to the IR/CO spectra of CoMo catalysts, three main components of promoted sites were evidenced at about 2057, 2073 and $2083 \mathrm{~cm}^{-1}$. Step-by-step in situ CVD Co deposition on Mo catalysts with different morphologies shows that bands at $\sim 2073$ and $\sim 2057 \mathrm{~cm}^{-1}$ characterize partially promoted sites whereas $\sim 2083 \mathrm{~cm}^{-1}$ is specific of completely promoted sites. Further, analysis of the promoted sites bands for catalysts supported on alumina, silica and titania that present different sulfide slab morphologies were performed. Firstly, all the results are in favor of Co promoting M-edge as well as S-edge. Secondly, variations with S-/M-edge ratio of Mo catalysts, 
with Co/Mo ratio deposited by CVD and parallel with DFT calculated CO frequencies allowed to assign 2072-74 and 2082-85 $\mathrm{cm}^{-1}$ bands to M-edge sites, respectively partially and completely promoted, and 2054-57 $\mathrm{cm}^{-1}$ to S-edge sites, partially promoted. Finally, parallel with HDS activity shows that catalytic activity cannot be directly related to the amount of CoMoS sites for CoMo catalysts supported on different oxides. This points out that the intrinsic activity of the three types of promoted sites is different. Indeed, $\mathrm{CoMo} / \mathrm{Al}_{2} \mathrm{O}_{3}$ that presents the highest $\mathrm{TOF}(\mathrm{CoMoS})$, has the highest proportion of partially promoted $\mathrm{M}$-edge sites. Whereas $\mathrm{CoMo} / \mathrm{TiO}_{2}$ catalyst that presents the lowest $\mathrm{TOF}(\mathrm{CoMoS})$, has the lowest proportion of partially promoted M-edge sites as well as the highest proportion of totally promoted M-edge sites. This highlights that partially promoted Medge sites $\left(v(\mathrm{CO})=2072-74 \mathrm{~cm}^{-1}\right)$ present greater intrinsic activity than totally promoted M-edge sites $\left(v(C O)=2082-85 \mathrm{~cm}^{-1}\right)$. This makes IR/CO not only an important tool for measuring the amount of non-promoted on M- and S-edge sites, and promoted sites but also a way to account for the different types of promoted sites and more specifically the most active types of promoted sites of CoMo supported catalysts.

\section{Acknowledgement}

E. Dominguez Garcia thanks the financial support of the French Ministry of Research through her PhD grant. J. Chen thanks The Natural Science Foundation of China (No. 21606047), and Normand IEPE Federation for the financial supports. Erwan Oliviero is thanked for the electron microscopy analysis.

\section{References}

[1] A. Tanimu, K. Alhooshani, Advanced Hydrodesulfurization Catalysts: A Review of Design and Synthesis, Energy \& Fuels. 33 (2019) 2810-2838.

[2] K.H. Kang, G.T. Kim, S. Park, P.W. Seo, H. Seo, C.W. Lee, A review on the Mo-precursors for catalytic hydroconversion of heavy oil, J. Ind. Eng. Chem. 76 (2019) 1-16..

[3] L. Oliviero, F. Maugé, P. Afanasiev, C. Pedraza-Parra, C. Geantet, Organic additives for hydrotreating catalysts: A review of main families and action mechanisms, Catal. Today. (2020).

[4] H. Topsøe, R. Candia, N. Topsøe, C. Haldor, On the state of the Co-Mo-S model, Bull. Soc. 
Chim. Belg. 93 (1984) 783-806.

[5] H. Topsøe, B.S. Clausen, R. Candia, C. Wivel, S. Morup, In situ Mossbauer emission spectroscopy studies of unsupported and supported sulfided CoMo hydrodesulfurization catalysts: Evidence for and nature of a Co-Mo-S phase, J. Catal. 68 (1981) 433-452.

[6] C. Wivel, R. Candia, B.S. Clausen, S. Mørup, H. Topsøe, On the catalytic significance of a CoMoS phase in CoMo Al2O3 hydrodesulfurization catalysts: Combined in situ Mössbauer emission spectroscopy and activity studies, J. Catal. 68 (1981) 453-463.

[7] C. Wivel, B.S. Clausen, R. Candia, S. Mørup, H. Topsøe, Mössbauer emission studies of calcined CoMo A12O3 catalysts: Catalytic significance of Co precursors, J. Catal. 87 (1984) 497-513.

[8] N.Y. Topsøe, H. Topsøe, Characterization of the structures and active sites in sulfided CoMo Al2O3 and NiMo Al2O3 catalysts by NO chemisorption, J. Catal. 84 (1983) 386-401.

[9] N.Y. Topsøe, H. Topsøe, O. Sorensen, B.S. Clausen, R. Candia, IR and AEM evidence for the edge location of the promotor atoms in Co-Mo-S type structures, Bull. Soc. Chim. Belg. 93 (1984) 727-733.

[10] H. Topsøe, B.S. Clausen, Active sites and support effects in hydrodesulfurization catalysts, Appl. Catal. 25 (1986) 273-293.

[11] N.Y. Topsøe, H. Topsøe, IR Spectroscopic Studies of the Nature of Surface Sites in Hydrotreating Catalysts, Stud. Surf. Sci. Catal. 26 (1986) 11-13.

[12] L. Portela, P. Grange, B. Delmon, The adsoprtion of Nitric Oxide on supported Co-Mo Hydrodesulfurization Catalysts: a Review, Catal. Rev. Sci. Eng. 37 (1995) 699-731. https://doi.org/10.1080/01614949508006452.

[13] S.F. Parker, A. Amorelli, Y.D. Amos, C. Hughes, N. Porter, J.R. Walton, IR spectroscopy of hydrotreating catalysts, J. Chem. Soc. Faraday Trans. 91 (1995) 517-524.

[14] J. Ramírez, P. Castillo, L. Cedeno, R. Cuevas, M. Castillo, J. Palacios, A. López-Agudo, Effect of boron addition on the activity and selectivity of hydrotreating CoMo/Al2O3 catalysts, Appl. Catal. A, Gen. 132 (1995) 317-334.

[15] N. Steinfeldt, D. Muller, H. Berndt, VOx species on alumina at high vanadia loadings and 
calcination temperature and their role in the ODP reaction, Appl. Catal. A Gen. 272 (2004) $201-213$.

[16] H.R. Reinhoudt, E. Crezee, A.D. Van Langeveld, P.J. Kooyman, J.A.R. Van Veen, J.A. Moulijn, Characterization of the active phase in $\mathrm{NiW} / \gamma-\mathrm{Al} 2 \mathrm{O} 3$ catalysts in various stages of sulfidation with FTIR(NO) and XPS, J. Catal. 196 (2000) 315-329.

[17] Z. Shuxian, W.K. Hall, G. Ertl, H. Knözinger, X-ray photoemission study of oxygen and nitric oxide adsorption on MoS2, J. Catal. 100 (1986) 167-175.

[18] A. Redey, J. Goldwasser, W.K. Hall, The surface chemistry of molybdena-alumina catalysts reduced in $\mathrm{H} 2$ at elevated temperatures, J. Catal. 113 (1988) 82-95.

[19] J. Goldwasser, S.M. Fang, M. Houalla, W.K. Hall, On the surface chemistry of molybdenaalumina catalysts prepared from $\mathrm{Mo}(\mathrm{CO}) 6$, J. Catal. 115 (1989) 34-51.

[20] J. Bachelier, J.C. Duchet, D. Cornet, Carbon-Monoxide and oxygen as probe molecules for HDS active-sites, Bull. Des Soc. Chim. Belges. 90 (1981) 1301-1309.

[21] J. Bachelier, M.J. Tilliette, M. Cornac, J.C. Duchet, J.C. Lavalley, D. Cornet, Sulfided cobalt-molybdenum/alumina catalysts: carbon monoxide chemisorption and surface structures, Bull. Des Soc. Chim. Belges. 93 (1984) 743-750.

[22] E. Delgado, G.A. Fuentes, C. Hermann, G. Kunzmann, H. Knozinger, Site characterizationon reduced and on sulfided Mo/Al2O3 catalysis by adsorption of probe molecules, Bull. Des Soc. Chim. Belges. 93 (1984) 735-742.

[23] M.I. Zaki, B. Vielhaber, H. Knozinger, Low-temperature CO adsorption and state of molybdena supported on alumina, titania, ceria and zirconia - An Infrared Spectroscopic investigation, J. Phys. Chem. 90 (1986) 3176-3183.

[24] M. Angulo, F. Maugé, J.C. Duchet, J.C. Lavalley, Formation of promoted sites from $\mathrm{Ni}(\mathrm{CO}) 4$ decomposition on sulfided $\mathrm{Mo} / \mathrm{Al} 2 \mathrm{O} 3$ catalysts. A comparative IR study with conventional Ni-Mo/A12O3 catalysts, using carbon monoxide as a probe molecule, Bull. Des Soc. Chim. Belges. 96 (1987) 925-930.

[25] X. Qin, X. Guo, R. Prada Silvy, P. Grange, B. Delmon, Characterization of sulfided CoMo/Al2O3 by CO NO co-adsorption with IR spectroscopy, in: M.J. Phillips, M. Teman (Eds.), Proc. 9th Int. Congr. Catal., The Chemical Institute of Canada: Ottawa, 1988, 
Calgary, 1988: pp. 66-73.

[26] F. Maugé, J.-C. Lavalley, FTIR Study of CO Adsorption on sulfided Mo/A12O3 unpromoted or promoted by metal Carbonyls: titration of sites, J. Catal. 137 (1992) 69-76.

[27] C. Dujardin, M.A. Lelias, J. van Gestel, A. Travert, J.C. Duchet, F. Maugé, Towards the characterization of active phase of (Co)Mo sulfide catalysts under reaction conditionsParallel between IR spectroscopy, HDS and HDN tests, Appl. Catal. A Gen. 322 (2007) 4657.

[28] J. Chen, F. Maugé, J. El Fallah, L. Oliviero, IR spectroscopy evidence of MoS2 morphology change by citric acid addition on MoS2/A12O3 catalysts - A step forward to differentiate the reactivity of M-edge and S-edge, J. Catal. 320 (2014) 170-179.

[29] E. Dominguez Garcia, J. Chen, E. Oliviero, L. Oliviero, F. Maugé, New insight into the support effect on HDS catalysts: evidence for the role of Mo-support interaction on the MoS2 slab morphology, Appl. Catal. B Environ. 260 (2020).

[30] A. Travert, C. Dujardin, F. Maugé, S. Cristol, J.F. Paul, E. Payen, D. Bougeard, Parallel between infrared characterisation and ab initio calculations of $\mathrm{CO}$ adsorption on sulphided Mo catalysts, Catal. Today. 70 (2001) 255-269.

[31] C. Dujardin, M.A. Lelias, J. van Gestel, A. Travert, J.C. Duchet, F. Maugé, Towards the characterization of active phase of (Co)Mo sulfide catalysts under reaction conditions-Parallel between IR spectroscopy, HDS and HDN tests, Appl. Catal. A Gen. 322 (2007) 4657.

[32] A. Travert, C. Dujardin, F. Maugé, E. Veilly, S. Cristol, J.F. Paul, E. Payen, CO Adsorption on CoMo and NiMo Sulfide Catalysts: A Combined IR and DFT Study, J. Phys. Chem. B. 110 (2006) 1261-1270.

[33] P. Stelmachowski, S. Sirotin, P. Bazin, F. Maugé, A. Travert, Speciation of adsorbed CO2 on metal oxides by a new 2-dimensional approach: 2D infrared inversion spectroscopy (2D IRIS), Phys. Chem. Chem. Phys. 15 (2013) 9335—9342.

[34] D.G. Cameron, J.K. Kauppinen, D.J. Moffatt, H.H. Mantsch, Precision in Condensed Phase Vibrational Spectroscopy, Appl. Spectrosc. 36 (1982) 245-250.

[35] W.A. House, D.H. Everett, Adsorption on heterogeneous surfaces, in: Spec. Period. Reports, 
Colloid Sci., 1983: pp. 1-58.

[36] M. Heuchel, P. Braeuer, M. Von Szombathely, U. Messow, W.D. Einicke, M. Jaroniec, Evaluation of the energy distribution function from liquid/solid adsorption measurements, Langmuir. 9 (1993) 2547-2554.

[37] A. Dąbrowski, P. Podkościelny, M. Bülow, Comparison of energy-distribution functions calculated for gas-solid and liquid-solid adsorption data, Colloids Surfaces A Physicochem. Eng. Asp. 212 (2003) 109-114.

[38] A. Travert, C. Fernandez, SpectroChemPy (Version 0.1), (2020).

[39] V. Labruyere, $\mathrm{PhD}$, Structure des sites sulfures des catalyseurs d'hydrotraitement: approche combinee par spcetroscopie IR et modelisation moleculaire, Université de Caen, France, 2014.

[40] F. Maugé, J.C. Lavalley, FT-IR study of carbon monoxide adsorption on sulfided molybdenum/alumina unpromoted or promoted by metal carbonyls: titration of sites, J. Catal. 137 (1992) 69-76.

[41] E. Le Guludec, L. Oliviero, J.P. Gilson, F. Maugé, M. Rebeilleau, V. De Grandi, S. van Donk, From Gas to Liquid Phase Sulfidation: An IR Spectroscopy Study, Catal. Letters. 142 (2012) 736-743.

[42] J. Chen, PhD, Catalyse d'hydrotraitement: effet de la pression de sulfuration et d'agent chélatant sur la morphologie et la réactivité des phases sulfures, Université de Caen, France, 2014.

[43] J. Chen, V. Labruyere, F. Maugé, A.-A. Quoineaud, A. Hugon, L. Oliviero, IR Spectroscopic Evidence for MoS2 Morphology Change with Sulfidation Temperature on MoS2/A12O3 Catalyst, J. Phys. Chem. C. 118 (2014) 30039-30044..

[44] C. Arrouvel, M. Breysse, H. Toulhoat, P. Raybaud, A density functional theory comparison of anatase (TiO2)- and gamma-Al2O3-supported MoS2 catalysts, J. Catal. 232 (2005) 161178.

[45] A.S. Walton, J. V Lauritsen, H. Topsøe, F. Besenbacher, MoS2 nanoparticle morphologies in hydrodesulfurization catalysis studied by scanning tunneling microscopy, J. Catal. 308 (2013) 306-318. 
[46] P. Raybaud, J. Hafner, G. Kresse, S. Kasztelan, H. Toulhoat, Structure, energetics, and electronic properties of the surface of a promoted MoS2 catalyst: An ab initio local density functional study, J. Catal. 190 (2000) 128-143.

[47] A.D. Gandubert, E. Krebs, C. Legens, D. Costa, D. Guillaume, P. Raybaud, Optimal promoter edge decoration of CoMoS catalysts: A combined theoretical and experimental study, Catal. Today. 130 (2008) 149-159. 